\title{
Attributable burden and expenditure of cardiovascular diseases and associated risk factors in Mexico and other selected mega-countries
}

\author{
Kenny Mendoza-Herrera \\ Instituto Nacional de Salud Publica \\ Andrea Pedroza-Tobías \\ University of California San Francisco \\ Cesar Hernández-Alcaraz \\ Instituto Nacional de Salud Publica \\ Leticia Ávila-Burgos \\ Instituto Nacional de Salud Publica

\section{Carlos A. Aguilar-Salinas} \\ Instituto Nacional de Ciencias Medicas y Nutricion Salvador Zubiran \\ Simón Barquera Cervera ( $\nabla$ sbarquera@insp.mx ) \\ Instituto Nacional de Salud Publica
}

\section{Research article}

Keywords: Mexico, Mega-countries, Cardiovascular diseases, Burden, Expenditure

Posted Date: July 12th, 2019

DOI: https://doi.org/10.21203/rs.2.11271/v1

License: (c) (i) This work is licensed under a Creative Commons Attribution 4.0 International License. Read Full License

Version of Record: A version of this preprint was published at International Journal of Environmental Research and Public Health on October 22nd, 2019. See the published version at https://doi.org/10.3390/ijerph16204041. 


\section{Abstract}

Background Cardiovascular diseases (CVD) represent a health and economic threat globally. This paper aims to describe this problem in Mexico and other selected mega-countries through a review of published literature and the exploration of secondary datasets. Method Mega-countries with low (Nigeria), middle (India), high

(China/Brazil/Mexico), and very high (the U.S./Japan) human development index (HDI) were included. The review was divided into two topics: prevalence of dyslipidemia and CVD economic impact. Search, screening, and filtering processes were conducted in electronic databases using MeSH terms by one trained researcher. Inclusion and exclusion criteria were considered for eligibility. Methods and results were reported according to the PRISMA statement. Information from datasets on epidemiologic CVD indicators was also extracted. Results Thirty-two studies were eligible. Heterogeneity in economic data and limited nationwide information on dyslipidemias prevalence in some countries were found. Hypertriglyceridemia and hypercholesterolemia were higher in Mexico compared to other countries. Dietary risk factors have a higher contribution on cardiovascular mortality in developing countries: e.g. 8.1-13.8\% Mexico, 11.3-13.0\% India vs. 0.078-8.9\% Japan, 6.5-10.7\% the U.S. Probability of dying prematurely from CVD in 2016 was higher in lower HDI countries: 23.3-22.5\% (low-middle), 17.0-15.7\% (high), and 14.6-8.4\% (very high). From 1990-2016, a greater decrease in cardiovascular mortality in developed countries was registered (-56.8\% Japan/-11.1\% India). In 2015, an expenditure of USD-PPP \$11.2 billion due to hypertension, myocardial infarction, atrial fibrillation, and heart failure was reported in Mexico (4\% from public health expenditure). CVD ranked first in health care expenditures in almost all these nations and this economic burden is expected to remain significant by 2030 , especially in the most populated or developed countries. Conclusions The higher burden of CVD and its significant economic impact, coupled with poor clinical practice and epidemiological surveillance, represents a greater challenge for Mexico and other developing mega-countries. Thus, governments and academia should secure resources to assure an optimal monitoring of cardiovascular risk factors. Educational models and medical practice must be improved to optimize the diagnosis of CVD and the prescription and adherence of their pharmacological and lifestyle treatments. Long-term benefits are expected from strengthening strategies to modify the food system.

\section{Background}

Currently, cardiovascular diseases (CVD) are considered one of the most relevant global health problems[1]. The global cumulative economic loss from not implementing strategies to tackle CVD and other chronic diseases from 2010 to 2030 is expected to be $\$ 47$ trillion US dollars (USD), which is equivalent to $75 \%$ of the 2010 gross domestic product (GDP)[2-5]. Due to the health and economic burden that these diseases generate, the World Health Organization (WHO) launched its action plan for prevention and control of chronic diseases 2013-2020, constituting a global initiative with a package of strategies to reduce the negative effects of CVD[3].

The high prevalence of obesity and chronic diseases, as well as the increase in mortality from these causes since the nineties, have placed Mexico in the spotlight of global health[6-8]. The national health surveys have allowed Mexico to identify dyslipidemia as the second most prevalent cardiovascular risk factor in adults, just after a body mass index (BMI) above $25 \mathrm{~kg} / \mathrm{m} 2[9]$. As in other countries[10,11], the Mexican food system has undergone several transformations in recent decades. This has caused a deterioration in diet, characterized by an increase in the consumption of ultra-processed food, sugar-sweetened beverages, and a poor intake of fruits, vegetables, and whole grains[12-17]. This scenario has been associated with the increased prevalence of obesity, dyslipidemias, diabetes, and CVD, which represents important challenges for the health system and economy[3,8-12,18]. 
In Mexico, CVD represent the leading cause of mortality, accounting for $20 \%$ of total deaths, from which $68.5 \%$ are caused by ischemic heart disease (IHD). Estimates indicate that $4 \%$ from the total health expenditure in 2006 was spent on addressing CVD. Furthermore, investment in prevention strategies is much lower than in treatment and control actions[2]. Seventy-three percent of diabetes, obesity, and CVD expenditures are absorbed by three Mexican public health institutions: the Ministry of Health (Spanish acronym: SS), the Mexican Social Security Institute (Spanish acronym: IMSS), and the Institute for Social Security and Services for State Workers (Spanish acronym: ISSSTE).

Mexico is one of the 14 most populated countries in the world, where $65 \%$ of global CVD mortality is concentrated. Among these countries, there is great cultural diversity and different epidemiological and nutrition transition stages can be observed. For example, though non-communicable chronic diseases are not the main health issue in less developed nations such as India and Nigeria, even a low prevalence of these conditions means a significant burden since they are highly-populated countries. Differently, Brazil, China, and Mexico are mainly dominated by a high prevalence of obesity and other risk factors. Even though a similar epidemiological scenario is observed in the U.S. and Japan, two of the most developed mega-countries, in the last years, they have been successful in decreasing the burden of some cardiovascular risk factors such as smoking[10].

Despite these differences, these countries have political and economic characteristics in common that influence the regulation of the food and health system and other sectors, and therefore, the epidemic of chronic diseases $[10,19,20]$. Because of this, the understanding of the dynamics of the CVD-related epidemiological and economic scenarios in Mexico can contribute to identify effective strategies and critical financial measures to diminish the burden associated with these conditions. In addition, exploring and comparing this situation among other mega-countries can also be useful to visualize reproducible solutions in this group of nations. Thus, this paper aims to describe the burden and national economic impact that CVD represent to Mexico, as well to complementary explore and compare these indicators from other selected mega-countries through a review of published literature and the exploration of secondary datasets.

\section{Methods}

A review of literature and exploration of secondary datasets on the epidemiological indicators of CVD and its risk factors, as well as on the expenditure generated by its medical costs in Mexico were carried out. Data of six selected mega-countries with a population of 100 million[21] and a low (Nigeria), middle (India), high (China, Brazil, and Mexico), or very high (the U.S. and Japan) human development index (HDI) were also included. The HDI is composed of three indicators: 1) health that considers life expectancy at birth; 2) education that considers the adult literacy rate and years of education; and 3) income with GDP per capita in international dollars. Thus, the HDI is an indicator that allows for a comprehensive comparison between countries[22].

\section{Literature review}

A literature review was conducted and reported following the standards provided in the PRISMA statement[23,24] (PRISMA checklist [see Additional file 1]). Searches were carried out in the databases PubMed and ScienceDirect. In addition, reference lists from studies were reviewed to gather more information. Google Scholar and ResearchGate platforms were used to search complementary information and studies in press. The review was divided into and separately conducted in two main topics: 1) prevalence of dyslipidemia and 2) attributable 
economic burden to CVD, both nationwide. The period of search and updating was between January 2017 and December 2018, and no language restriction was applied.

Between 1993 and 2006 an increase in the burden of cardiovascular risk factors was documented in Mexico through the first health population-based surveys[7]. For this reason, the first general inclusion criterion for the identification process was literature published in and related to the period between 2006 and 2018. Searches were also limited to the availability of full abstracts and studies in humans. Studies without clearly reported methods were excluded. Search strategies for each topic were composed mainly of MeSH terms, but free vocabulary was also considered. Search strings are available in supplementary table 1 (see Additional file 2). Screening, filtering, and eligibility processes were performed for each topic.

Given the high burden that these risk factors represent in the development and control of CVD, the first search was focused on the prevalence of high triglycerides (TG), high total cholesterol (TC), low high-density lipoprotein cholesterol (HDL-c), and high low-density lipoprotein cholesterol (LDL-c) in healthy adults 18 years old. The terms used in this review were "dyslipidemia" (or "dyslipidemias") and "prevalence" (or "epidemiology"). Additionally, titles and abstracts of the identified articles were screened and filtered looking for the terms of lipid alterations, lipid abnormalities, proportion, patterns, trends, and population-based survey. For the eligibility process, the order of the following inclusion criteria and study characteristics were considered: 1) the most recent population-based surveys nationwide; 2) the most recent metanalyses or systematic reviews nationwide; 3) the most recent population-based surveys at regional level, and 4) studies with samples from multiple cities. Studies and information related to comorbidity of dyslipidemia with other conditions were excluded.

The second search was concentrated on estimates associated with economic burden attributable to CVD. CVDs included in the 10th revision of the International Statistical Classification of Diseases and Related Health Problems (ICD-10) and their risk factors were considered in this stage. The terms used on this search were "cardiovascular disease" (or "cardiovascular diseases") and "cost" (or "economics"). The following vocabulary was considered for screening and filtering of abstracts and titles: expenditure, expenses, charges, spending, spent, economy, economic burden, economic impact, coronary heart disease (CHD), angina, heart disease, ischemic heart disease, myocardial infarction, myocardial ischemia, stroke, cerebral ischemic vascular event, ischemic vascular event, and vascular event. The main outcomes for this review were expenditures, rank of economic impact among different causes, fraction of relevant economic indicators spent on CVD, and projected economic losses and expenses. Full texts of cost-effectiveness studies were not reviewed. The following inclusion criteria were considered in the eligibility process: 1) information nationwide; 2) report of monetary indicators, and 3) use of cost components, cost of illness methods, and modelling approaches. Microeconomic data were excluded (e.g. cost of treatment per patient year).

Identification and screening processes were carried out by one trained researcher. Afterwards, each potential article was fully reviewed in order to fill out the inclusion criteria checklist and to exclude inadequate studies. All the studies classified as eligible were read by the team of this study and their inclusion was done by consensus. Data on authors, titles, databases, study design, year of estimation, main indicators, reported methodology, and main outcomes of the reviewed and included studies were extracted and summarized.

In order to standardize economic information, estimate expenditures from Mexico were deflated by considering the accumulated inflation until the year of the most recent information: $2006-2016=46.81 \%$; $2008-2016=32.82 \%$; 2014-2016 $=5.56 \%$, and 2015-2016 $=3.36 \%$. Additionally, these estimates were adjusted by purchasing power 
parities (PPP) for 2016 (1 USD-PPP = \$8.87 pesos). Meanwhile, Mexican economic projections are presented as they appear in the literature. Economic data in currencies from other mega-countries were calculated to USD using the average yearly exchange rate. In addition, data from the studies that provide estimates in USD were kept and presented in this way.

\section{Review and analysis of secondary databases}

Databases from the Mexican national surveys of health and nutrition (Spanish acronym: ENSANUT) 2006 and $2012[25,26]$ were analyzed to estimate the prevalence of obesity and hypertension in the northern, central-western, central, and southern regions of Mexico. Datasets of medicines purchases from the IMSS were reviewed in order to obtain information of expenditure on statins in Mexico[27].

Data from the Global Burden of Disease (GBD) study 2017[28] related to age-standardized mortality rates of CVD and the attributable percentage of metabolic and dietary risk factors to cardiovascular deaths were reviewed. The metabolic risk factors were high systolic blood pressure, high LDL-c, high fasting plasma glucose, excess body weight, and impaired kidney function. The dietary risk factors were a low intake of nuts/seeds, vegetables, fruits, legumes, whole grains, fiber, polyunsaturated fatty acids [PUFAs] -3 from fish and seafood, a high intake of trans fatty acids, sodium, processed meat, and sugar-sweetened beverages. In the case of Mexico, information on IHD, ischemic stroke, CVD in general, and all the previous risk factors were considered. For the other selected countries, data on only CVD in general and four risk factors were included: 1) low intake of seeds and grains; 2) low intake of polyunsaturated fatty acids (PUFAs) -3; 2) hypertension; and 3) hypercholesterolemia.

The WHO Global Health Observatory databases[29] were explored. From these, the indicator that reflects the probability of dying between 30 and 70 years old (premature death) from any CVD, cancer, diabetes, or chronic respiratory disease, was obtained. The information was reviewed for 2000 and 2016 in the seven mega-countries.

A narrative synthesis of the information identified in the literature reviews and the secondary datasets was conducted. In order to complement this article, some strategies to decrease the burden of CVD were discussed (no extensive review was performed for the search of this particular literature).

\section{Results}

\section{Literature search}

The detailed PRISMA flow diagram for the reviews on prevalence of dyslipidemia and CVD economic burden in seven mega-countries can be visualized in Figure 1. After removing duplicates, a total of 5,776 records in the search for dyslipidemias prevalence in the analyzed mega-countries were identified. One hundred thirteen articles were fully reviewed and 13 of them were included. The number of identified records for the economic burden of CVD in these nations was 8,745 after duplicates, from which 201 were totally read. A total of 19 articles were included in this review. A summary of all the fully reviewed and included studies can be found in the

\section{Supplementary Tables 2-5 (see Additional file 2).}

The nationwide and regional representative prevalence of hypertriglyceridemia, hypercholesterolemia, hypoalphalipoproteinemia, and high LDL-C, as well as the prevalence of Mexican adults eligible for pharmacological and lifestyle lipid-lowering therapy according to cardiovascular risk profiles in 2006, were obtained from two studies derived from ENSANUT[9,30]. Eligibility profiles in the latter study were based on lipid- 
lowering treatment recommendations considering the absolute risk of having CHD according to the National Cholesterol Education Program (NCEP) and the sex- and age-specific Framingham score tables[30,31].

The most recent information about the prevalence of dyslipidemia in the U.S.[32-34] and Japan[35,36] was obtained from studies based on analyses of the National Health and Nutrition Examination Survey (NHANES) and from a review that exposed information of the Japanese National Health and Nutrition Survey 2015 respectively. For India, evidence of 2008-2010 from the Indian Council of Medical Research India Diabetes Study (ICMR-INDIAB study) was included[37]. Data from Nigeria were obtained from a study based on population-based surveys of four geopolitical areas[38], and data from China came from a 2014 metanalysis[39] and a nationally representative survey carried out between 2013 and 2014[40]. In the case of Brazil, this information was collected from a prospective study with 15,105 participants[41] and the prevalence of self-reported high cholesterol levels was identified in a study based on the National Health Survey 2013[42].

Expenditure estimates of CVD in Mexico were identified in a report from 2006. These included information of curative medical care, medical products, prevention actions, health management, laboratory services, research, and technological development in the SS, IMSS, ISSSTE, and the private sector[2]. Estimates related to expenses on medical consultation, laboratory tests, medications, and hospitalization in the SS and IMSS from addressing hypertension and IHD nationwide were obtained from a study derived from ENSANUT 2012[43].

Information on the expenditure generated by five CVDs in 2015 in Mexico was identified in a study in press. These estimates considered the economic burden of medical treatment, and formal and informal medical care in the Mexican health system. In addition, they included the loss of productivity and welfare caused by hypertension, acute myocardial infarction, atrial fibrillation, and heart failure nationwide[44].

Total costs associated with hypertension expected for 2016 in Mexico, including indirect and direct expenditures for SS, IMSS, ISSSTE, and users, were identified in a study published in 2015[45]. These estimates were based on national registries and were calculated through a modelling approach considering the changes in cases and demand of health services in the health system. Other study of 2017 with similar sources of information and methodology was included. In this article, estimates concerned only older adults in Mexico[46]. Additionally, information of the IMSS expenditures on atorvastatin and pravastatin in 2016 was obtained from its online datasets of medicines purchases. These statins are part of the official catalogue of drugs from the Mexican public health sector.

Projections of the attributable expenditure to IHD, acute myocardial infarction, and stroke in Mexico were identified in a 2014 study. These estimates were based on USD of 2010 and three hypothetic scenarios of obesity rate changes between 2010 and 2050: 1) no reduction of the average BMI in the Mexican population; 2) reduction of $1.0 \%$, and 3 ) of $5.0 \%[47-50]$. These trends were based on BMI data from Mexican health and nutrition surveys of $1993,1999,2000$, and 2006.

Data on the national economic burden of CVD in the other mega-countries were collected from a included series of studies and reports[51-70]. Beginning with countries of a low and middle HDI, data of projected economic losses due to CVD in India between 2012 and 2030 were identified in a study based on the World Health Organization's EPIC model of economic growth. Information from Nigeria was obtained from a study that aimed to estimate the expected loss of GDP to 2015 in 23 low- and middle-income countries through an economic growth model. 
Two studies related to CVD expenditures in China were included. The first one was related to estimates of foregone GDP projected to 2030 based on a human capital augmented production function, and the second one to hospitalization expenses in 2014. The included studies for Brazil concerned the economic impact of hypertension, heart failure, myocardial infarction, and atrial fibrillation including direct and indirect costs calculated through a cost of illness framework, as well as estimates on direct and indirect cost of CVD nationwide in 2015.

Evidence of CVD economic impact for mega-countries with a very high HDI were identified in seven sources. Expenditure estimates on ambulatory, emergency, inpatient, and nursing facility care, as well as pharmaceuticals in 2013 for the U.S. were identified in one study. Data on direct and indirect costs between 2013 and 2035 were found in two reports from the American Heart Association. Current and projected estimates associated with informal caregiving for patients with CVD were in other article (2015-2030, zero-inflated binomial model controlling for sociodemographic factors). For Japan, information on expenditures generated by direct medical care, morbidity and mortality, as well as by expenditures from insurance benefits and those incurred by family and friends for medical care at the household or community level, was identified in a single study. Other study based on the Cost of Illness method and modelling estimations reporting the economic impact of ischemic heart disease in 2014, and between 2017 and 2029, was also included. In addition, projections of foregone GDP to 2030 based on a human capital augmented production function were identified.

A total of 16 reports and studies about strategies against CVD were reviewed for discussion. The included interventions were those identified by the WHO as the most cost-effective[3] and other similar strategies studied in isolation among the selected countries.

\section{CVD risk factors}

After obesity, hypoalphalipoproteinemia (HDL-c $<50 \mathrm{mg} / \mathrm{dL}$ for women and $<40 \mathrm{mg} / \mathrm{dL}$ for men) and high LDL-c $(100 \mathrm{mg} / \mathrm{dL}$ ) were the most prevalent cardiovascular risk factors in Mexican adults in 2006 (Table 1). In the same year, the prevalence of hypercholesterolemia in northern and central Mexico was higher than in the other regions.

Prevalence of hypertension (systolic/diastolic blood pressure $\geq 140 / \geq 90 \mathrm{~mm} \mathrm{Hg}$ ) in Mexico did not show substantial changes in the analyzed period. This condition was observed in three out of every ten Mexican adults and its prevalence in the northern region was the highest in 2006 and 2012. According to the newest data from the ENSANUT, prevalence of high blood pressure in Mexican adults was 25.5\% in 2016 (data is not shown on tables) [71].

The most recent prevalence of hypertriglyceridemia and hypercholesterolemia was higher in Mexico compared to that in India, Nigeria (TG $\geq 150 \mathrm{mg} / \mathrm{dL}$ and TC $\geq 200 \mathrm{mg} / \mathrm{dL}$ ), China, Japan ( $\mathrm{TG} \geq 200 \mathrm{mg} / \mathrm{dL}$ and TC $\geq 240$ $\mathrm{mg} / \mathrm{dL}$ ), and in the U.S. (TG $\geq 150 \mathrm{mg} / \mathrm{dL}$ and $\mathrm{TC} \geq 240 \mathrm{mg} / \mathrm{dL}$ ) (Table 1 and Table 2). The highest prevalence of high LDL-c were found in Brazil (57.6\% [women] 58.5\% [men], LDL-c $\geq 130 \mathrm{mg} / \mathrm{dL})$, Mexico (46.0\%, LDL-c $\geq 130$ $\mathrm{mg} / \mathrm{dL}$ ), and in the U.S. (27\%, LDL-c $\geq 160 \mathrm{mg} / \mathrm{dL}$ [low risk groups], $\geq 130 \mathrm{mg} / \mathrm{dL}$ [intermediate-risk groups], and $\geq 100 \mathrm{mg} / \mathrm{dL}$ [high risk groups]). India had the highest prevalence of hypoalphalipoproteinemia ( $<50 \mathrm{mg} / \mathrm{dL}$ for women and $<40 \mathrm{mg} / \mathrm{dL}$ for men).

\section{Prevalence of eligible Mexican adults for lipid-lowering therapy}

In $2006,36.3 \%$ of Mexican adults were eligible for therapy of lifestyle changes and $24.2 \%$ for pharmacological treatment considering their cardiovascular risk profile (Table 3)[30]. From the Mexican adults with cardiovascular 
risk profile one, $70.5 \%$ were eligible to follow pharmacological and lifestyle treatment. From the adults with diabetes, $71.4 \%$ were candidates for both treatments. Around $39.0 \%$ of the adults with two or more cardiovascular risk factors were candidates for lifestyles changes and $23.9 \%$ for medicines. The prevalence of Mexican adults with cardiovascular risk profiles two, three, and four that were candidates for treatment of lifestyle changes was $30.7 \%, 55.3 \%$, and $80.5 \%$ respectively. Meanwhile, the prevalence of adults with these profiles that required drugs was of $10.9 \%, 55.3 \%$, and $80.5 \%$, respectively[30].

\section{CVD mortality attributable to metabolic and dietary risk factors}

According to the GBD study in 2017, dietary risks factors contributed with $48.4 \%$ of the total CVD deaths, and with $65.7 \%$ and $23.2 \%$ of the mortality associated with IHD and ischemic stroke in Mexico, respectively (Table 4). The trans fatty acids intake contributed with $6.7 \%$ of the total CVD deaths and $10.2 \%$ of the IHD deaths in Mexican population. The percentage of CVD and IHD deaths attributable to low PUFAs -3 intake was $8.1 \%$ and $13.0 \%$ respectively. The contribution of low PUFAs -3 and nuts/seeds intake to CVD mortality was higher in less developed countries (11.3\% and $13.0 \%$ India; $8.1 \%$ and $13.8 \%$ Mexico) compared to the developed countries $(0.078 \%$ and $8.9 \%$ Japan; $6.5 \%$ and $10.7 \%$ the U.S.)[28]. Table 2 and Table 4.

Metabolic risk factors were associated with $77.4 \%$ of the total CVD deaths, $84.1 \%$ of the IHD deceases, and $68.6 \%$ of the ischemic stroke mortality in Mexico. The high LDL-c ranked second among the metabolic risk factors with major influence on mortality caused by CVD and IHD (just after high systolic blood pressure), with a contribution of $30.0 \%$ and $44.6 \%$ to the deaths from these conditions in Mexican individuals. This lipid abnormality ranked third among metabolic risk factors that contributed most to ischemic stroke mortality, with $20.7 \%$ of its deaths. In every single selected country, the contribution of the high LDL-c to total CVD deaths was equal or higher than $15.9 \%$, and in Mexico it had the highest contribution[28]. Table 2 and Table 4.

Probability of premature death by CVD and other chronic diseases in 2016 was of $23.3-22.5 \%$ for low-middle HDI countries, $17.0-15.7 \%$ for high HDI countries, and of 14.6-8.4\% for very high HDI countries[29]. From 1990 to 2017, a relative decrease in age-standardized CVD mortality rates of $11.1 \%, 27.3 \% 22.0 \%, 21.2 \%, 47.9 \%, 56.8 \%$ and $41.0 \%$ in India, Nigeria, Mexico, China, Brazil, Japan and the U.S., was observed respectively[29] (Table 2).

\section{Attributable expenditures to CVD}

In 2006, CVD care concentrated 55\% of the total public and private health expenditures directed to address diabetes, obesity, and CVD in Mexico. The expenditures on CVD in USD-PPP were $\$ 812.5$ million in the ISSSTE, $\$ 1.8$ billion in the IMSS, and $\$ 343.2$ million in the SS. The equivalent percentages of the annual budget of these institutions were $23.2 \%, 11.0 \%$, and $2.4 \%$, respectively. Between $48.4 \%$ and $66.0 \%$ of the total expenditures on chronic diseases in these three institutions corresponded to CVD. The percentage of the annual budget spent on CVD drugs was $2.8 \%$ in the ISSSTE, $1.9 \%$ in the IMSS, and $0.2 \%$ in the SS. The expenditures on control and prevention actions for CVD from the annual budget of the SS was $2.3 \%$ and $0.02 \%$, respectively[2].

In 2012, the IMSS allocated USD-PPP \$1.3 billion and USD-PPP \$719.8 million to address hypertension and IHD respectively, including ambulatory consultation, laboratory tests, drugs, and hospitalization expenditures. The SS spent USD-PPP \$425.9 million on hypertension and USD-PPP \$107 million on IHD in the same areas[43]. In 2015, hypertension, myocardial infarction, atrial fibrillation, and heart failure represented an expense of USD-PPP \$11.2 billion in Mexico, including the loss of productivity and welfare[44]. 
The SS, IMSS, and ISSSTE were expected to respectively allocate USD-PPP \$1.6, \$2.7, and \$1.1 billion to address the increased demand of health services associated with hypertension in 2016. The expenditures expected for users surpassed the sum of these previous amounts, being USD-PPP \$5.6 billion[45]. A similar pattern in the proportion of these expenses among health care providers and users over 60 years old was observed by 2015[46]. In 2016, the IMSS spent USD-PPP \$6.6 million on atorvastatin and USD-PPP \$16.1 million on pravastatin, and the average unit price of these statins was USD-PPP \$1.1 and USD-PPP \$1.08, respectively[27] (Table 5).

In the case that the average BMI in the Mexican population remains static from 2010 to 2050, the economic burden of IHD, myocardial infarction, and stroke would mean a nationwide accumulated expenditure of USD \$23 billion. A reduction of $1.0 \%$ in the average BMI in the population would reduce USD \$986 million from the accumulated CVD expenditures in this period, while a decrease of 5.0\% would save USD \$753 million to 20 years and USD \$2.1 billion to 40 years[50] (Figure 2).

CVD ranked first among expenditures derived from health care for different causes in India, Mexico, Japan, and the U.S, and it represented the second place in China. The highest expenditure for addressing CVD was reported in the evidence from the U.S., USD \$316.1 billion in 2013[64] and \$555 billion in 2016[60]. Projections indicate that the economic losses generated by CVD will be of USD \$918 billion[64]-\$1.1 trillion[60], USD \$756 billion[58], USD \$2.17 trillion[57], and of \$1.5 trillion[58] for the U.S., Japan, India, and China by 2030-2035, respectively. One study in Japan indicated an expected decrease in the economic burden generate by IHD, reducing from USD \$15.3 billion in 2017 to USD \$11.5 billion by 2029[62]. Projections were not found for Brazil (Table 2).

\section{Strategies to decrease the burden of CVD}

According to the $\mathrm{WHO}$, strategies such as reducing high sodium intake, decreasing tobacco use, and optimization of pharmacological treatment, are the Best Buy Interventions against CVD[3]. An additional investment of USD \$1.5 per capita per year to scale up these strategies between 2015 and 2030, would mean avoiding the incidence of eight million IHD cases and 13 million strokes in countries where the highest chronic disease burden is concentrated[56].

Studies in some mega-countries have shown how great beneficial the implementation of actions similar to the Best Buy Interventions could be to the primary prevention of CVD. For instance, in the U.S., adherence to healthy diet and other lifestyle recommendations are associated with a reduction of up to $\approx 92 \%$ of cardiovascular risk in the population[72-74]. In India, a reduction of $3 \mathrm{~g} / \mathrm{d}$ in population salt consumption through regulations would prevent $\approx 400,000$ and $\approx 81,000$ events and deaths from CVD over 30 years, respectively[54]. Unhealthy food taxation is also a promising strategy against CVD. The projections in Mexico indicate that a reduction of $10 \%$ in the consumption of sugar-sweetened beverages through taxes could prevent $\approx 46,300 \mathrm{CHD}$ cases and 14,200 myocardial infarctions over 10 years[75]. In India, the $10 \%$ palm oil tax could reduce $\approx 363,000$ deaths by myocardial infarction in 10 years[55]. Another kind of policy to reduce the CVD burden are the subsidies for healthy food. For example, a $10 \%$ reduction in the prices of fruits, vegetables, and nuts/seeds through this strategy, could prevent $0.6 \%(\approx 2,213), 0.8 \%(\approx 2,873)$, and $0.9 \%(\approx 3,148)$ of the total annual CHD deaths in the U.S., respectively[76] (Table 2).

The control of hypercholesterolemia[77], hypertension[78], and diabetes[77], as well as smoking cessation[79] in the secondary prevention level, are essential to promptly reduce the CVD burden[80]. In order to achieve an effective treatment of these conditions, various elements and actions are of high priority. 1) well-trained multidisciplinary health team (e.g. through skills certification); 2) adjustments to health schools' curriculums (involving the newest 
treatment guidelines); 3) family incorporation to therapies; 4) mutual-help groups with motivation strategies; 5) improvements on accessibility and availability of medications; and 6) well-structured interventions (e.g. by using electronic health records)[81]. Once the treatment optimization has been achieved, substantial benefits could be expected. For instance, evidence in the U.S. indicate that optimal achievement of management goals of hypertension could reduce $\approx 56,000$ events and $\approx 13,000$ deaths from CVD annually[78,82]. In China, optimizing and broadening lipid-lowering therapy coverage could avoid $\approx 850,000$ cases of myocardial infarction and $\approx 300,000$ deaths from CVD each year[63]. In Japan, a reduction of $\approx 66 \%$ in the risk of cardiovascular events in healthy adult men has been associated with smoking cessation for a period equal or greater of four years[83] (Table 2).

\section{Discussion}

Compared to developed mega-countries, Mexico and the nations with a similar o lesser HDI experience greater challenges related to CVD. In these countries, dietary risk factors contribute more to cardiovascular mortality. Furthermore, there is a greater probability of premature death from CVD and in the last decades, there has been a lower decrease in mortality rates. The economic burden from CVD was significant both in developing and developed analyzed countries, given that it represents the main health expenditure. Making this comparison was not possible for Nigeria and Brazil, since the information was not identified. Additionally, projections indicate that this economic threat will remain significant for these countries by 2030-especially for China, India, and the U.S.

The inverse association between the development and the burden of chronic diseases has also been described at sub-national level in various countries[84]. In southern Mexico, there was a greater increase in mortality from diabetes and CVD at the end of the 20th century in comparison to the northern region, which is more developed[6,84]. Because of this, authorities should not only implement a comprehensive strategy, but they should also design targeted strategies that consider the needs of every region. In the southern region, for example, coverage of antihypertensive drugs should be expanded to reduce the high prevalence of adults with hypertension who are not undergoing this treatment[71]. On the other hand, the higher prevalence of hypercholesterolemia observed in this study is coupled with low-quality diets with greater energy density in the northern region[85,86]. This could be mitigated by improving the food environment, dietary recommendations, and increasing availability of and adherence to lipid-lowering treatment in this country area.

This paper gives an overview of the CVD burden in seven mega-countries. One of the identified barriers in some developing countries is the limited monitoring of CVD risk in epidemiological surveillance systems. In Nigeria, for example, there is no representative national data regarding the population's lipid profile[87]. A similar situation occurs in three of the most important national surveys in India[88]. In Brazil, the population's lipid concentration has been only evaluated in a few cities[89] and the assessment of hypercholesterolemia in the National Health Survey is limited to self-report[42]. Therefore, governments and academic groups from these countries should secure resources to carry out population level studies that describe the prevalence of dyslipidemia. Prioritizing this would allow for a better design, evaluation, and reformulation of strategies to combat CVD.

The development of hypercholesterolemia, hypertriglyceridemia, and hypoalphalipoproteinemia is associated with the presence of obesity and its lifestyle-related determinants[90-93]. These four CVD risk factors are the most prevalent in Mexico and have been reported to be even greater than in some of the analyzed countries. In Mexico and India, adults with overweight are respectively 5.25 and 4.15 times more likely to have mixed dyslipidemia and hypertriglyceridemia[37,94], while up to $95.2 \%$ of American individuals with obesity have lipid abnormalities[95]. 
Considering that reductions starting at $1 \%$ of the Mexican population's average BMI would save up to $\$ 986$ million USD in the next years[50], intensive strategies to improve dietary patterns, foster active lifestyles, and increase access to pharmacological treatments that normalize bodyweight and the lipid profile are vital to moderate costs generated by CVD.

Statins are the most utilized medications in Mexico to treat CVD due to their cost-effectiveness[96]. Their average unit cost for Mexican health public institutions is $\approx$ USD-PPP \$1[27]. However, the potential benefit of this treatment for Mexicans' cardiovascular health is mainly hampered by low adherence to medication as in other countries[9799]. In addition, low nutritional quality diets[14,16,100] and the high prevalence of physical inactivity and sedentarism[101,102] in the country are major constraints for the statins positive effects. Inaccurate classification of cardiovascular risk profiles by medical professionals and the lack of diagnostic, are other significant challenges to treatment. This leads to poor management of high-risk patients or extraneous therapies in less-risk subjects that generate unnecessary costs[103]. This practice, in addition to high prescribed doses of statins and having a high cardiovascular risk profile, have been associated with the non-compliance of the LDL-C goals in Mexico, Brazil, and India[103].

These challenges highlight the need to explore new care and treatment options, especially for population groups with the greatest cardiovascular risk. One alternative includes pharmaceuticals that enhance the receptor activity of the LDL-c molecules and its uptake from plasma to the cells. Until now, these are indicated in a small proportion of cases at cardiovascular risk and have begun to be studied in clinical randomized control trials[104,105]. Nonetheless, due to its approximate cost/person/year of $\$ 14,000$ USD in the U.S., they are not cost-effective in clinical practice[106,107]. Given the high prevalence of population experiencing unaffordability of CVD medicines including aspirin, $\beta$ blockers, angiotensin-converting enzyme inhibitors, and statins in mega-countries, such as Brazil, China, and India[108], cheaper drugs still being a priority. A lower-cost option is a polypill made from the combination of active substances that produce drug synergism. Its use and formulation with patent-free substances have been proposed as strategies to improve adherence and cost-effectiveness of treatment for CVD[109-117]. However, consistent evidence is needed to support a generalized use.

The lack of comparable studies on CVD-related expenditures limits the differentiation of the economic burden produced by these diseases in the analyzed countries. Data from developed countries are obtained through comprehensive economic analyses, but with distinct methodologies and indicators. In estimates from the U.S., for example, costs were considered from hospital care, ambulance and emergency room, nursing services, and medications. In contrast, estimates from Japan were obtained from a study which adapted the Cost of IIIness method, taking into account direct costs of medical attention, morbidity, mortality, and the long-term costs and economic burden for families[52,68]. In Mexico, four recent studies developed through different solid methods, national registries, and population-based datasets cover economic estimates for hypertension, IHD, heart failure, myocardial infarction, and atrial fibrillation from 2012 to 2017[43-46]. On the other hand, though a considerable number of studies at regional level focused on catastrophic health expenditures or with micro-costing approaches in India and Nigeria was identified, the nationwide current information on total CVD-related costs was limited. Notoriously, methodological frameworks of some of these studies were not clearly reported (see Additional file 2).

Despite this heterogeneity, it is possible to suggest that the financial burden of CVD in developing countries may be higher than reported if all types of costs were considered. For example, estimates in Mexico indicate that only four kinds of these diseases consumed approximately USD-PPP $\$ 11.2$ billion in 2015 or the equivalent to $\approx 4 \%$ of the total health expenses in the country[44]. Although this study, considerably similar to another in Brazil[59], concerns 
direct costs such as patients' hospital care and the loss of economic productivity, these statistics and those from previous years would increase if out-of-pocket expenditures were included, which represent $44 \%$ of the total health expenditure and more than $50 \%$ of the total expenses associated with hypertension in Mexican adults[45,46]. Outof-pocket CVD expenses for 15 months in countries such as China and India have been reported to be 15.0-40.1\% and 39.3-54.9\% of the annual household expenses, respectively[118]. In addition, catastrophic health expenditure in some of the analyzed mega-countries is considerably higher in households where family members with hypertension live[119], and it is significantly high even for insured individuals[120]. In any case, the financial stress due to CVD experienced by families should be considered in future comprehensive studies.

The management of CVD is a large-scale challenge. In $2006, \approx 60 \%$ of Mexican adults required interventions to reduce their cardiovascular risk[30]. Indeed, this prevalence could be greater considering the current population ageing and if the updated guidelines were applied in a new study76. Optimal treatment on the current cases is a key piece to diminish the cardiovascular burden in the short term[81]. However, deficiencies in health systems, the complexity of illness, and the high cost of secondary care[81,121], make difficult effectively treat CVD in countries such as Mexico[81]. Because of this, authorities from each country should opt to allocate resources to a systematic strategy focused on improving health care personnel practice through the restructuration of study plans in the universities and the encouragement of lifelong learning, strengthening family inclusion and motivation techniques in medical care, and on guaranteeing technological infrastructure and drugs for an adequate management and treatment of patients.

The burden of CVD also should be addressed through effective interventions based on the life-course approach and environmental strategies. The modification of the food system through taxes to sugar sweetened beverages (SSBs), an understandable front-of-pack nutrition label, and subsidies for healthy foods are complementary components to prevent cardiovascular risk factors, CVD, and its comorbidities in the next generations. They favor healthy diets and facilitate informed consumption decisions in general and at-risk population[3,122,123]. Furthermore, the SSBs taxation has been shown to reduce sales of these products in Mexico and other countries[124-129], which in the long-term could decrease cardiovascular risk factors such as high BMI and hyperglycemia in the population bringing considerable economic benefits associated with CVD. Accordingly, this fiscal measure should be considered a policy with great potential if it is adopted as a CVD prevention strategy.

\section{Conclusion}

Currently, CVD generate a significant health and economic burden particularly in Mexico and other six megacountries that hold approximately $50 \%$ of the global population. Although the increase of morbidity and cardiovascular mortality in the developed countries from this group has slowed in the last years, projections show that costs related to CVD will remain significant in the next decades. Consequently, investment in strategies and prevention policies must continue and be raised in order to reduce the incidence of these diseases and their risk factors.

The developing mega-countries face greater obstacles due to CVD than developed countries. They also experience shortcomings in clinical practice associated with failure to reach lipid profile targets and deficiencies in epidemiological surveillance instruments that limit cardiovascular monitoring in the population. This suggests an urgent need to implement well-structured interventions at the primary and secondary care level in order to optimize diagnosis, the prescription of pharmacological treatment and lifestyles, and the adherence to these interventions. Moreover, the evaluation of dyslipidemias through national representative studies must also be strengthened.

Page $12 / 32$ 
Governments must centralize their efforts, so the food system does not favor the obesogenic environment, as this would translate into a substantial reduction in the economic and health burden caused by cardiovascular-related diseases in the next generations. The loss of sustainable development that CVD would eventually cause to the most populated countries in the world will only be mitigated through the implementation of cost-effective strategies at all the medical care levels and by adopting a preventive health approach.

\section{List Of Abbreviations}

CVD: cardiovascular disease; IHD: ischemic heart disease; USD: US dollars; GDP: gross domestic product; WHO: World Health Organization; BMI: body mass index; SS (Spanish acronym): Ministry of Health; IMSS (Spanish acronym): Mexican Social Security Institute; ISSSTE (Spanish acronym): Institute for Social Security and Services for State Workers; HDI: human development index; TG: triglycerides; TC: total cholesterol; HDL-c: high-density lipoprotein cholesterol; LDL-c: low-density lipoprotein cholesterol; CHD: coronary heart disease; MI: myocardial ischemia; PPP: purchasing power parities; ENSANUT (Spanish acronym): Mexican national survey of health and nutrition; GBD: Global Burden of Disease; PUFAs: polyunsaturated fatty acids; NCEP: National Cholesterol Education Program; NHANES: The National Health and Nutrition Examination Survey; ICMR-INDIAB study: Indian Council of Medical Research India Diabetes Study.

\section{Declarations}

\section{Ethics approval and consent to participate}

Not applicable.

\section{Consent for publication}

Information on prevalence of some cardiovascular disease risk factors in Mexico (Table 1 and Table 2, section of Mexico) was taken from the databases of the Mexican National Surveys 2006 and 2012. These studies were previously approved by the Biosecurity, Research, and Ethics Committees of the Mexican National Institute of Public Health (INSP) and written informed consent was obtained from the participants. The rest of the information was obtained from previously published sources or publicly available datasets, and its format was adapted to be presented in this article. All the authors have approved the manuscript

\section{Availability of data and material}

The datasets analyzed during the current study are available in the GBD repository, [http://www.healthdata.org/gbd], WHO Health Observatory repository [https://www.who.int/gho/en/], and IMSS repository [http://compras.imss.gob.mx/]. Datasets from ENSANUT are available from the corresponding author on reasonable request.

\section{Competing interests}

The authors have declared that they have no competing interests.

\section{Funding}


Development of research in this article was supported by the financing provided to the Mexican National Institute of Public Health (Spanish acronym: INSP) by Sanofi under registration number DIREGL07857 (SB); the Fogarty International Center of the National Institutes of Health (http://www.fic.nih. gov/Pages/Default.aspx) under Award Number R03TW009061 (SB, APT). Also is supported in part by the Robert Wood Johnson Foundation grant under Award Number 74155 ( $\mathrm{CHA}, \mathrm{KMH})$. The funders had no role in study design, data collection and analysis, decision to publish, or preparation of the manuscript.

\section{Authors' contributions}

Conceptualization: KMH, APT, CHA, SB. Formal Analysis: KMH, APT, LAB, CAAS, SB. Funding Acquisition: SB, CAAS. Project Administration: KM, CHA. Writing - original draft: $\mathrm{KMH}, \mathrm{APT}$, SB. Writing - review \& editing: KAM, LAB, CAAS, SB. All authors read and approved the final manuscript.

\section{Acknowledgements}

Not applicable.

\section{References}

1. Global, regional, and national age-sex specific all-cause and cause-specific mortality for 240 causes of death, 1990-2013: a systematic analysis for the Global Burden of Disease Study 2013. Lancet (London, England). 2015 Jan;385(9963):117-71.

2. Ávila-Burgos L, Cahuana-Hurtado L, González-Domínguez D, Aracena-Genao B, Montañez-Hernández JC, ServánMori EE, RiveraPeña G. Cuentas en diabetes mellitus, enfermedades cardiovasculares y obesidad, México 2006. Ciudad de México Cuernavaca, México: Instituto Nacional de Salud Publica.

3. WHO. Global action plan for the prevention and control of noncommunicable diseases 2013-2020. World Heal Organ [Internet]. 2013;102. Available from: http://apps.who.int/iris/bitstream/10665/94384/1/9789241506236_eng.pdf

4. Bloom DE, Cafiero E, Jané-Llopis E, Abrahams-Gessel S, Bloom LR, Fathima S, et al. The global economic burden of noncommunicable diseases. Program on the Global Demography of Aging; 2012.

5. Laslett LJ, Alagona P, Clark BA, Drozda JP, Saldivar F, Wilson SR, et al. The worldwide environment of cardiovascular disease: Prevalence, diagnosis, therapy, and policy issues: A report from the american college of cardiology. J Am Coll Cardiol [Internet]. 2012;60(25 SUPPL.):S1-49. Available from:

http://dx.doi.org/10.1016/j.jacc.2012.11.002

6. Barquera S, Tovar-Guzmán V, Campos-Nonato I, González-Villalpando C, Rivera-Dommarco J. Geography of diabetes mellitus mortality in Mexico: An epidemiologic transition analysis. Arch Med Res. 2003;34(5):407-14.

7. Villalpando S, Shamah-Levy T, Rojas R, Aguilar-Salinas CA. Trends for type 2 diabetes and other cardiovascular risk factors in Mexico from 1993-2006. Salud Publica Mex [Internet]. 2010;52(2). Available from:

http://www.scielo.br/scielo.php?script=sci_arttext\&pid=S0036-36342010000700011\&lng=en\&nrm=iso\&tlng=en 
8. Barquera S, Campos-Nonato I, Hernández-Barrera L, Pedroza A, Rivera-Dommarco J a. Prevalencia de obesidad en adultos mexicanos 2000-2012. Salud Publica Mex [Internet]. 2013;55(.2):151-60. Available from:

http://www.scielosp.org/scielo.php?script=sci_arttext\&pid=S0036-36342013000800012\&lng=en\&nrm=iso\&tlng=es

9. Aguilar-Salinas CA, Gomez-Perez FJ, Rull J, Villalpando S, Barquera S, Rojas R. Prevalence of dyslipidemias in the Mexican National Health and Nutrition Survey 2006. Salud Publica Mex. 2010;52 Suppl 1:S44-53.

10. Barquera S, Pedroza-Tobias A, Medina C. Cardiovascular diseases in mega-countries. Curr Opin Lipidol. 2016;27(4):329-44.

11. Barquera S, Pedroza-Tobías A, Medina C, Hernández-Barrera L, Bibbins-Domingo K, Lozano R, et al. Global Overview of the Epidemiology of Atherosclerotic Cardiovascular Disease. Arch Med Res. 2015;46(5):328-38.

12. Rivera JA, Barquera S, Campirano F, Campos I, Safdie M, Tovar V. Epidemiological and nutritional transition in Mexico: rapid increase of non-communicable chronic diseases and obesity. Public Health Nutr. 2002 Feb;5(1A):113-22.

13. Stevens G, Dias RH, Thomas KJA, Rivera JA, Carvalho N, Barquera S, et al. Characterizing the epidemiological transition in Mexico: National and subnational burden of diseases, injuries, and risk factors. PLoS Med. 2008;5(6):0900-10.

14. Stern D, Piernas C, Barquera S, Rivera JA, Popkin BM. Caloric beverages were major sources of energy among children and adults in Mexico, 1999-2012. J Nutr. 2014 Jun;144(6):949-56.

15. Barquera S, Campirano F, Bonvecchio A, Hernandez-Barrera L, Rivera JA, Popkin BM. Caloric beverage consumption patterns in Mexican children. Nutr J. 2010 Oct;9:47.

16. Barquera S, Hernandez-Barrera L, Tolentino ML, Espinosa J, Ng SW, Rivera JA, et al. Energy intake from beverages is increasing among Mexican adolescents and adults. J Nutr. 2008 Dec;138(12):2454-61.

17. Flores M, Macias N, Rivera M, Lozada A, Barquera S, Rivera-Dommarco J, et al. Dietary patterns in Mexican adults are associated with risk of being overweight or obese. J Nutr. 2010 Oct;140(10):1869-73.

18. Barquera S, Campos-Nonato I, Hernandez-Barrera L, Villalpando S, Rodriguez-Gilabert C, Durazo-Arvizu R, et al. Hypertension in Mexican adults: results from the National Health and Nutrition Survey 2006. Salud Publica Mex. 2010;52 Suppl 1:S63-71.

19. Popkin BM. Nutrition Transition and the Global Diabetes Epidemic. Curr Diab Rep. 2015;15(9).

20. Douglas KA, Yang G, McQueen D V., Puska P. Mega Country Health Promotion Network Surveillance Initiative. In: Douglas KA, Yang G, McQueen D V., Puska P, editors. Global Behavioral Risk Factor Surveillance. Boston, MA: Springer, 2003. p. 179-96.

21. Kennedy E. Healthy lifestyles. healthy people - The Mega Country Health Promotion Network. Asia Pac J Clin Nutr. 2002;11 Suppl 8:S738-S739.

22. Stewart F. Capabilities and Human Development: Beyond the individual - the critical role of social institutions and social competencies. Hum Dev Reports - UNDP. 2013;03:1-20. 
23. Moher D, Liberati A, Tetzlaff J, Altman DG, Altman D, Antes G, et al. Preferred reporting items for systematic reviews and meta-analyses: The PRISMA statement (Chinese edition). J Chinese Integr Med. 2009;7(9):889-96.

24. Liberati A, Altman DG, Tetzlaff J, Mulrow C, Gøtzsche PC, loannidis JPA, et al. The PRISMA statement for reporting systematic reviews and meta-analyses of studies that evaluate health care interventions: explanation and elaboration. J Clin Epidemiol [Internet]. 2009;62(10):e1-34. Available from:

http://www.ncbi.nlm.nih.gov/pubmed/19631507

25. Olaiz-Fernández G, Rivera-Dommarco J, Shamah-Levy T, Rojas R, Villalpando Hernández S, Hernández-Avila M, Sepúlveda-Amor J. Encuesta Nacional de Salud y Nutrición 2006. Cuernavaca, México: Instituto Nacional de Salud Pública, 2006.

26. Gutiérrez JP, Rivera-Dommarco J, Shamah-Levy T, Villalpando-Hernández S, Franco A, Cuevas-Nasu L, RomeroMartínez M, Hernández-Ávila M. Encuesta Nacional de Salud y Nutrición 2012. Resultados Nacionales. Cuernavaca, México: Instituto Nacional de Salud Púb.

27. Instituo Mexicano del Seguro Social (IMSS). Portal de compras del IMSS [Internet]. [cited 2018 Jul 9]. Available from: http://compras.imss.gob.mx/

28. Institute for Health Metrics and Evaluation (IHME). GBDCompareDataVisualization. Seattle, WA: IHME, University of Washington, 2016. Available from http:// vizhub.healthdata.org/gbd-compare. (Accessed [January 20, 2018]).

29. Organization WH. Global health observatory data repository. 2013.

30. Gomez-Perez FJ, Rojas R, Villalpando S, Barquera S, Rull J, Aguilar-Salinas CA. Prevention of cardiovascular disease based on lipid lowering treatment: a challenge for the Mexican health system. Salud Publica Mex. 2010;52 Suppl 1:S54-62.

31. Executive Summary of The Third Report of The National Cholesterol Education Program (NCEP) Expert Panel on Detection, Evaluation, And Treatment of High Blood Cholesterol In Adults (Adult Treatment Panel III). JAMA. 2001 May;285(19):2486-97.

32. Carroll MD, Fryar CD, Nguyen DT. Total and High-density Lipoprotein Cholesterol in Adults: United States, 20152016 Key findings Data from the National Health and Nutrition Examination Survey. 2015;(290):2015-6. Available from: https://www.cdc.gov/nchs/data/databriefs/db290_table.pdf\#2.

33. Toth PP, Potter D, Ming EE. Prevalence of lipid abnormalities in the United States: the National Health and Nutrition Examination Survey 2003-2006. J Clin Lipidol. 2012;6(4):325-30.

34. Kuklina E V, Carroll MD, Shaw KM, Hirsch R. Trends in high LDL cholesterol, cholesterol-lowering medication use, and dietary saturated-fat intake: United States, 1976-2010. NCHS Data Brief [Internet]. 2013;(117):1-8. Available from: http://www.pubmedcentral.nih.gov/articlerender.fcgi?

artid=4401469\&tool=pmcentrez\&rendertype=abstract

35. National Health and Nutrition Survey in Japan. Ministry of Health, Labour, and Welfare; 2015. Available at: http://www.mhlw.go.jp/toukei itiran/gaiyo/k-eisei.html. 
36. Lin CF, Chang YH, Chien SC, Lin YH, Yeh HY. Epidemiology of Dyslipidemia in the Asia Pacific Region. Int J Gerontol. 2018;12(1):2-6.

37. Joshi SR, Anjana RM, Deepa M, Pradeepa R, Bhansali A, Dhandania VK, et al. Prevalence of dyslipidemia in urban and rural India: the ICMR-INDIAB study. PLoS One. 2014;9(5):e96808.

38. Oguoma VM, Nwose EU, Ulasi II, Akintunde AA, Chukwukelu EE, Bwititi PT, et al. Cardiovascular disease risk factors in a Nigerian population with impaired fasting blood glucose level and diabetes mellitus. BMC Public Health [Internet]. 2017;17(1):1-9. Available from: http://dx.doi.org/10.1186/s12889-016-3910-3

39. Huang Y, Gao L, Xie X, Tan SC. Epidemiology of dyslipidemia in Chinese adults: meta-analysis of prevalence, awareness, treatment, and control. Popul Health Metr. 2014;12(1):28.

40. Zhang M, Deng Q, Wang L, Huang Z, Zhou M, Li Y, et al. Prevalence of dyslipidemia and achievement of lowdensity lipoprotein cholesterol targets in Chinese adults: A nationally representative survey of 163,641 adults. Int $\mathrm{J}$ Cardiol [Internet]. 2018;260:196-203. Available from: https://doi.org/10.1016/j.ijcard.2017.12.069

41. Santos RD, Bensenor IM, Pereira AC, Lotufo PA. Dyslipidemia according to gender and race: The Brazilian Longitudinal Study of Adult Health (ELSA-Brasil). J Clin Lipidol. 2016;10(6):1362-8.

42. Lotufo PA, Santos RD, Sposito AC, Bertolami M, Rocha-Faria Neto J, Izar MC, et al. Self-Reported HighCholesterol Prevalence in the Brazilian Population: Analysis of the 2013 National Health Survey. Arq Bras Cardiol. 2017;411-6.

43. Figueroa-Lara A, Gonzalez-Block MA, Alarcon-Irigoyen J. Medical Expenditure for Chronic Diseases in Mexico: The Case of Selected Diagnoses Treated by the Largest Care Providers. PLoS One. 2016;11(1):e0145177.

44. Stevens B, Pezzullo L, Verdian L, Tomlinson J, Estrada-Aguilar C, George A, et al. The economic burden of hypertension, heart failure, myocardial infarction, and atrial fibrillation in Mexico. Arch Cardiol Mex. 2018 Apr;

45. Arredondo A, Cuadra SM, Duarte MB. Challenges of the epidemiological and economic burdens associated with hypertension in middle income countries: Evidence from Mexico Chronic Disease epidemiology. BMC Public Health [Internet]. 2015;15(1):1-7. Available from: http://dx.doi.org/10.1186/s12889-015-2430-x

46. Arredondo A, Duarte MB, Cuadra SM. Epidemiological and financial indicators of hypertension in older adults in Mexico: challenges for health planning and management in Latin America. Int J Health Plann Manage. 2017;32(2):e121-36.

47. Butland B, Jebb S, Kopelman P et al. Foresight Tackling Obesities: Future Choices - Project Report. 2007. London: Government Office for Science.

48. Kopelman P, Jebb SA \& Butland B. Executive summary: Foresight: “Tackling Obesities: Future Choices” project. Obes Rev. 2007;8:Suppl1:vi-ix.

49. McPherson K, Marsh T \& Brown M Foresight. Tackling Obesities: Future Choices - Modelling Future Trends in Obesity \& Their Impact on Health. 2007. London: Government Office for Science. 
50. Rtveladze K, Marsh T, Barquera S, Sanchez Romero LM, Levy D, Melendez G, et al. Obesity prevalence in Mexico: impact on health and economic burden. Public Health Nutr. 2014 Jan;17(1):233-9.

51. Stam-Slob MC, van der Graaf Y, Greving JP, Dorresteijn JAN, Visseren FLJ. Cost-Effectiveness of Intensifying Lipid-Lowering Therapy With Statins Based on Individual Absolute Benefit in Coronary Artery Disease Patients. J Am Heart Assoc. 2017 Feb;6(2).

52. Dieleman JL, Baral R, Birger M, Bui AL, Bulchis A, Chapin A, et al. US Spending on Personal Health Care and Public Health, 1996-2013. JAMA. 2016 Dec;316(24):2627-46.

53. Birabi BN, Oke KI, Dienye PO, Okafor UC. Cost burden of post stroke condition in Nigeria: a pilot study. Glob J Health Sci. 2012;4(6):17.

54. Basu S, Stuckler D, Vellakkal S, Ebrahim S. Dietary salt reduction and cardiovascular disease rates in India: a mathematical model. PLoS One. 2012;7(9):e44037.

55. Basu S, Babiarz KS, Ebrahim S, Vellakkal S, Stuckler D, Goldhaber-Fiebert JD. Palm oil taxes and cardiovascular disease mortality in India: economic-epidemiologic model. BMJ. 2013;347:f6048.

56. Bertram MY, Sweeny K, Lauer JA, Chisholm D, Sheehan P, Rasmussen B, et al. Investing in non-communicable diseases: an estimation of the return on investment for prevention and treatment services. Lancet. 2018;

57. Bloom DE, Cafiero-Fonseca ET, McGovern ME, Prettner K, Stanciole A, Weiss J, et al. The macroeconomic impact of non-communicable diseases in China and India: Estimates, projections, and comparisons. J Econ Ageing [Internet]. 2014;4:100-11. Available from: http://dx.doi.org/10.1016/j.jeoa.2014.08.003

58. Bloom DE, Chen S, Kuhn M, McGovern ME, Oxley L, Prettner K. The economic burden of chronic diseases: Estimates and projections for China, Japan, and South Korea. J Econ Ageing [Internet]. 2018 Sep 26 [cited 2019 Jun 19];100163. Available from: https://www.sciencedirect.com/science/article/pii/S2212828X18300744

59. Stevens B, Pezzullo L, Verdian L, Tomlinson J, George A, Bacal F. The Economic Burden of Heart Conditions in Brazil. Arq Bras Cardiol. 2018;(November 2016):29-36.

60. Association AH. Cardiovascular disease: A costly burden for America projections through 2035. 2017.

61. Dunbar SB, Khavjou OA, Bakas T, Hunt G, Kirch RA, Leib AR, et al. Projected Costs of Informal Caregiving for Cardiovascular Disease: 2015 to 2035: A Policy Statement From the American Heart Association. Circulation. 2018 May;137(19):e558-77.

62. Gochi T, Matsumoto K, Amin R, Kitazawa T, Seto K, Hasegawa T. Cost of illness of ischemic heart disease in Japan: A time trend and future projections. Environ Health Prev Med. 2018;23(1):1-7.

63. Stevens W, Peneva D, Li JZ, Liu LZ, Liu G, Gao R, et al. Estimating the future burden of cardiovascular disease and the value of lipid and blood pressure control therapies in China. BMC Health Serv Res. 2016 May;16:175.

64. Benjamin EJ, Blaha MJ, Chiuve SE, Cushman M. Heart Disease and Stroke Statistics-2017 Update. Vol. 135, Circulation. 2017. 146-603 p. 
65. Levi J, Segal LM, Juliano C. Prevention for a healthier America: investments in disease prevention yield significant savings, stronger communities. Trust for America's Health; 2008.

66. Chen W-W, Gao R-L, Liu L-S, Zhu M-L, Wang W, Wang Y-J, et al. China cardiovascular diseases report 2015: a summary. J Geriatr Cardiol [Internet]. 2017;14(1):1-10. Available from:

http://www.ncbi.nlm.nih.gov/pubmed/28270835\%0Ahttp://www.pubmedcentral.nih.gov/articlerender.fcgi? artid=PMC5329726

67. Wang S, Marquez P, Langenbrunner J, Niessen L, Suhrcke M, Song F. Toward a healthy and harmonious life in China: stemming the rising tide of non-communicable diseases. Washingt World Bank. 2011;

68. Matsumoto K, Hanaoka S, Wu Y, Hasegawa T. Comprehensive Cost of Illness of Three Major Diseases in Japan. J Stroke Cerebrovasc Dis. 2017;26(9):1934-40.

69. Siqueira A de SE, Siqueira-Filho AG de, Land MGP. Analysis of the Economic Impact of Cardiovascular Diseases in the Last Five Years in Brazil. Arq Bras Cardiol. 2017;109(1):39-46.

70. Abegunde DO, Mathers CD, Adam T, Ortegon M, Strong K. The burden and costs of chronic diseases in lowincome and middle-income countries. Lancet. 2007;370(9603):1929-38.

71. Campos-Nonato I, Hernández-Barrera L, Pedroza-Tobías A, Medina C, Barquera S. Hipertensión arterial en adultos mexicanos: prevalencia, diagnóstico y tipo de tratamiento. Ensanut MC 2016. Salud Publica Mex [Internet]. 2018;60(3, may-jun):233. Available from: http://www.saludpublica.mx/index.php/spm/article/view/8813

72. Chomistek AK, Chiuve SE, Eliassen AH, Mukamal KJ, Willett WC, Rimm EB. Healthy lifestyle in the primordial prevention of cardiovascular disease among young women. J Am Coll Cardiol. 2015 Jan;65(1):43-51.

73. Stampfer MJ, Hu FB, Manson JE, Rimm EB, Willett WC. Primary prevention of coronary heart disease in women through diet and lifestyle. N Engl J Med. 2000 Jul;343(1):16-22.

74. Chiuve SE, Rexrode KM, Spiegelman D, Logroscino G, Manson JE, Rimm EB. Primary prevention of stroke by healthy lifestyle. Circulation. 2008 Aug;118(9):947-54.

75. Sánchez-Romero LM, Penko J, Coxson PG, Fernández A, Mason A, Moran AE, et al. Projected Impact of Mexico's Sugar-Sweetened Beverage Tax Policy on Diabetes and Cardiovascular Disease: A Modeling Study. PLoS Med. 2016;13(11):1-17.

76. Peñalvo JL, Cudhea F, Micha R, Rehm CD, Afshin A, Whitsel L, et al. The potential impact of food taxes and subsidies on cardiovascular disease and diabetes burden and disparities in the United States. BMC Med. 2017;15(1):1-13.

77. Stone NJ, Robinson JG, Lichtenstein AH, Bairey Merz CN, Blum CB, Eckel RH, et al. 2013 ACC/AHA guideline on the treatment of blood cholesterol to reduce atherosclerotic cardiovascular risk in adults: a report of the American College of Cardiology/American Heart Association Task Force on Practice Guidelines. J Am Coll Cardiol. 2014 Jul;63(25 Pt B):2889-934.

78. James PA, Oparil S, Carter BL, Cushman WC, Dennison-Himmelfarb C, Handler J, et al. 2014 evidence-based guideline for the management of high blood pressure in adults: report from the panel members appointed to the 
Eighth Joint National Committee (JNC 8). JAMA. 2014 Feb;311(5):507-20.

79. Ockene IS, Miller NH. Cigarette smoking, cardiovascular disease, and stroke: a statement for healthcare professionals from the American Heart Association. American Heart Association Task Force on Risk Reduction. Circulation. 1997 Nov;96(9):3243-7.

80. The CDC Diabetes Cost-effectiveness Group. Cost-effectiveness of Intensive Glycemic Control, Intensified Hypertension Control, and Serum Cholesterol Level Reduction for Type 2 Diabetes. Jama [Internet].

2002;287(19):2542. Available from: http://jama.jamanetwork.com/article.aspx?doi=10.1001/jama.287.19.2542

81. Córdova-Villalobos JA, Barriguete-Meléndez JA, Lara-Esqueda A, Barquera S, Rosas-Peralta M, Hernández-Avila $\mathrm{M}$, et al. Chronic non-communicable diseases in Mexico: Epidemiologic synopsis and integral prevention. Salud Publica Mex [Internet]. 2008;50(5):419-27. Available from: http://bvs.insp.mx/rsp/_files/File/2008/Septiembre Octubre/9-panorama.pdf\%5Cnhttp://ovidsp.ovid.com/ovidweb.cgi?

T=JS\&PAGE=reference\&D=emed8\&NEWS=N\&AN=18852939\%5Cnhttp://www.ncbi.nlm.nih.gov/pubmed/18852939

82. Moran AE, Odden MC, Thanataveerat A, Tzong KY, Rasmussen PW, Guzman D, et al. Cost-Effectiveness of Hypertension Therapy According to 2014 Guidelines. N Engl J Med [Internet]. 2015 Jan 28;372(5):447-55. Available from: http://dx.doi.org/10.1056/NEJMsa1406751

83. Kondo T, Osugi S, Shimokata K, Honjo H, Morita Y, Maeda K, et al. Smoking and Smoking Cessation in Relation to All-Cause Mortality and Cardiovascular Events in 25,464 Healthy Male Japanese Workers. Circ J [Internet]. 2011;75(12):2885-92. Available from: http://joi.jlc.jst.go.jp/JST.JSTAGE/circj/CJ-11-0416?from=CrossRef

84. Rivera J, Barquera S, González-Cossío T, Olaiz G, Sepúlveda J. Nutrition transition in Mexico and in other Latin American countries. Nutr Rev. 2004;62(7 Pt 2):S149-57.

85. Marron-Ponce JA, Sanchez-Pimienta TG, Louzada ML da C, Batis C. Energy contribution of NOVA food groups and sociodemographic determinants of ultra-processed food consumption in the Mexican population. Public Health Nutr. 2018 Jan;21(1):87-93.

86. Ponce X, Rodriguez-Ramirez S, Mundo-Rosas V, Shamah T, Barquera S, Gonzalez de Cossio T. Dietary quality indices vary with sociodemographic variables and anthropometric status among Mexican adults: a cross-sectional study. Results from the 2006 National Health and Nutrition Survey. Public Health Nutr. 2014 Aug;17(8):1717-28.

87. National Population Commission - NPC/Nigeria and ICF International. Demographic and Health Survey 2013. N. Abuja, Nigeria; 2014.

88. Dandona R, Pandey A, Dandona L. A review of national health surveys in India. World Heal Organ Bull. 2016;94(4):286-96.

89. Garcez MR, Pereira JL, Fontanelli M de M, Marchioni DML, Fisberg RM. Prevalence of Dyslipidemia According to the Nutritional Status in a Representative Sample of São Paulo. Arq Bras Cardiol. 2014;476-84.

90. Franssen R, Monajemi H, Stroes ESG, Kastelein JJP. Obesity and dyslipidemia. Med Clin North Am. 2011 Sep;95(5):893-902. 
91. Klop B, Elte JWF, Cabezas MC. Dyslipidemia in obesity: mechanisms and potential targets. Nutrients. 2013 Apr,5(4):1218-40.

92. Castelli W. Lipoproteins and cardiovascular disease: biological basis and epidemiological studies. Value Heal J Int Soc Pharmacoeconomics Outcomes Res. 1998;1(2):105-9.

93. Hruby A, Hu FB. The Epidemiology of Obesity: A Big Picture. Pharmacoeconomics. 2015 Jul;33(7):673-89.

94. Barquera S, Flores M, Olaiz-Fernández G, Monterrubio E, Villalpando S, González C, et al. Dyslipidemias and obesity in Mexico. Salud Publica Mex. 2007;49:s338-47.

95. Guo F, Garvey WT. Trends in Cardiovascular Health Metrics in Obese Adults: National Health and Nutrition Examination Survey (NHANES), 1988-2014. J Am Heart Assoc. 2016 Jul;5(7).

96. Mitchell AP, Simpson RJ. Statin cost effectiveness in primary prevention: a systematic review of the recent costeffectiveness literature in the United States. BMC Res Notes. 2012 Jul;5:373.

97. Berra K. Lipid-lowering therapy today: Treating the high-risk cardiovascular patient. J Cardiovasc Nurs. 2008;23(5):414-21.

98. Schwiesow SJ, Nappi JM, Ragucci KR. Assessment of compliance with lipid guidelines in an academic medical center. Ann Pharmacother. 2006 Jan;40(1):27-31.

99. Zafrir B, Cohen S. Primary prevention in high-risk dyslipidemic patients without an established cardiovascular disease: Undertreatment and rationale for lipid-lowering therapy. Eur J Intern Med. 2006 Nov;17(7):495-9.

100. Rivera JA, Pedraza LS, Aburto TC, Batis C, Sanchez-Pimienta TG, Gonzalez de Cosio T, et al. Overview of the Dietary Intakes of the Mexican Population: Results from the National Health and Nutrition Survey 2012. J Nutr. 2016 Sep;146(9):1851S-5S.

101. Medina C, Janssen I, Campos I, Barquera S. Physical inactivity prevalence and trends among Mexican adults: Results from the National Health and Nutrition Survey (ENSANUT) 2006 and 2012. BMC Public Health. 2013;13(1).

102. Medina C, Tolentino-Mayo L, Lopez-Ridaura R, Barquera S. Evidence of increasing sedentarism in Mexico City during the last decade: Sitting time prevalence, trends, and associations with obesity and diabetes. PLoS One. 2017;12(12):e0188518.

103. Danchin N, Almahmeed W, Al-Rasadi K, Azuri J, Berrah A, Cuneo CA, et al. Achievement of low-density lipoprotein cholesterol goals in 18 countries outside Western Europe: The International ChoLesterol management Practice Study (ICLPS). Eur J Prev Cardiol. 2018;

104. Sabatine MS, Giugliano RP, Keech AC, Honarpour N, Wiviott SD, Murphy SA, et al. Evolocumab and Clinical Outcomes in Patients with Cardiovascular Disease. N Engl J Med. 2017 May;376(18):1713-22.

105. Schwartz GG, Szarek M, Bhatt DL, et al. Alirocumab in patients after acute coronary syndrome. Orlando, FL: American College of Cardiology, 2018.

106. Kazi DS, Moran AE, Coxson PG, Penko J, Ollendorf DA, Pearson SD, et al. Cost-effectiveness of PCSK9 Inhibitor Therapy in Patients With Heterozygous Familial Hypercholesterolemia or Atherosclerotic Cardiovascular 
Disease. JAMA. 2016 Aug;316(7):743-53.

107. Svatikova A, Kopecky SL. Cholesterol Management in the Era of PCSK9 Inhibitors. Curr Cardiol Rep. 2017 Sep;19(9):83.

108. Khatib R, McKee M, Shannon H, Chow C, Rangarajan S, Teo K, et al. Availability and affordability of cardiovascular disease medicines and their effect on use in high-income, middle-income, and low-income countries: An analysis of the PURE study data. Lancet [Internet]. 2016;387(10013):61-9. Available from: http://dx.doi.org/10.1016/S0140-6736(15)00469-9

109. Yusuf S, Islam S, Chow CK, Rangarajan S, Dagenais G, Diaz R, et al. Use of secondary prevention drugs for cardiovascular disease in the community in high-income, middle-income, and low-income countries (the PURE Study): a prospective epidemiological survey. Lancet (London, England). 2011 Oct;378(9798):1231-43.

110. Wirtz VJ, Kaplan WA, Kwan GF, Laing RO. Access to Medications for Cardiovascular Diseases in Low- and Middle-Income Countries. Circulation. 2016 May;133(21):2076-85.

111. Beall RF, Schwalm J-DR, Huffman MD, McCready T, Yusuf S, Attaran A. Could patents interfere with the development of a cardiovascular polypill? J Transl Med. 2016 Aug;14(1):242.

112. Bangalore S, Kamalakkannan G, Parkar S, Messerli FH. Fixed-dose combinations improve medication compliance: a meta-analysis. Am J Med. 2007 Aug;120(8):713-9.

113. Huffman MD. The Polypill: From Promise to Pragmatism. PLoS Med. 2015 Aug;12(8):e1001862.

114. Elley CR, Gupta AK, Webster R, Selak V, Jun M, Patel A, et al. The efficacy and tolerability of "polypills": metaanalysis of randomised controlled trials. PLoS One. 2012;7(12):e52145.

115. Gupta AK, Arshad S, Poulter NR. Compliance, safety, and effectiveness of fixed-dose combinations of antihypertensive agents: a meta-analysis. Hypertens (Dallas, Tex 1979). 2010 Feb;55(2):399-407.

116. Yusuf S, Pais P, Afzal R, Xavier D, Teo K, Eikelboom J, et al. Effects of a polypill (Polycap) on risk factors in middle-aged individuals without cardiovascular disease (TIPS): a phase Il, double-blind, randomised trial. Lancet (London, England). 2009 Apr,373(9672):1341-51.

117. Rodgers A, Patel A, Berwanger O, Bots M, Grimm R, Grobbee DE, et al. An international randomised placebocontrolled trial of a four-component combination pill ("polypill") in people with raised cardiovascular risk. PLoS One. 2011;6(5):e19857.

118. Huffman MD, Rao KD, Pichon-Riviere A, Zhao D, Harikrishnan S, Ramaiya K, et al. A cross-sectional study of the microeconomic impact of cardiovascular disease hospitalization in four low- and middle-income countries. PLoS One. 2011;6(6):e20821.

119. Si Y, Zhou Z, Su M, Ma M, Xu Y, Heitner J. Catastrophic healthcare expenditure and its inequality for households with hypertension: Evidence from the rural areas of Shaanxi Province in China. Int J Equity Health. 2017;16(1):1-12. 
120. Sun J, Liabsuetrakul T, Fan Y, Mcneil E. Protecting patients with cardiovascular diseases from catastrophic health expenditure and impoverishment by health finance reform. Trop Med Int Heal. 2015;20(12):1846-54.

121. Baeza-Cruz G, Peniche-Otero G, Alva-Esqueda ME, Naranjo-Muedano M, Soria-Suárez N, Morales-Flores HJ. Análisis de costo de la enfermedad, del tratamiento, las complicaciones e intervenciones de la hipercolesterolemia en México en 2016. Value Heal Reg Issues [Internet]. 2018;17:56-63. Available from:

http://dx.doi.org/10.1016/j.vhri.2017.12.003

122. Thow AM, Downs S, Jan S. A systematic review of the effectiveness of food taxes and subsidies to improve diets: understanding the recent evidence. Nutr Rev. 2014 Sep;72(9):551-65.

123. Hawkes C, Organization WH. Nutrition labels and health claims: the global regulatory environment. 2004;

124. Colchero MA, Popkin BM, Rivera JA, Ng SW. Beverage purchases from stores in Mexico under the excise tax on sugar sweetened beverages: observational study. BMJ. 2016 Jan;352:h6704.

125. Colchero MA, Rivera-Dommarco J, Popkin BM, Ng SW. In Mexico, Evidence Of Sustained Consumer Response Two Years After Implementing A Sugar-Sweetened Beverage Tax. Health Aff (Millwood). 2017 Mar,36(3):564-71.

126. Batis C, Rivera JA, Popkin BM, Taillie LS. First-Year Evaluation of Mexico's Tax on Nonessential Energy-Dense Foods: An Observational Study. PLoS Med. 2016 Jul;13(7):e1002057.

127. Silver LD, Ng SW, Ryan-lbarra S, Taillie LS, Induni M, Miles DR, et al. Changes in prices, sales, consumer spending, and beverage consumption one year after a tax on sugar-sweetened beverages in Berkeley, California, US: A before-and-after study. PLoS Med. 2017 Apr,14(4):e1002283.

128. Falbe J, Thompson HR, Becker CM, Rojas N, McCulloch CE, Madsen KA. Impact of the Berkeley Excise Tax on Sugar-Sweetened Beverage Consumption. Am J Public Health. 2016 Oct;106(10):1865-71.

129. Bascunan J, Cuadrado C. Effectiveness of sugar-sweetened beverages taxes to reduce obesity: evidence brief for policy. Medwave. 2017 Oct;17(8):e7054.

\section{Tables}


Table 1. Prevalence of CVD risk factors according to Mexican National Surveys, 2006 and 2012

\begin{tabular}{|c|c|c|c|c|c|c|c|c|c|c|}
\hline & \multicolumn{2}{|c|}{ México } & \multicolumn{2}{|c|}{ North } & \multicolumn{2}{|c|}{ Center } & \multicolumn{2}{|c|}{ Center-west } & \multicolumn{2}{|c|}{ South } \\
\hline & $2006^{b}$ & $2012^{c}$ & $2006^{b}$ & $2012^{c}$ & $2006^{b}$ & $2012^{\mathrm{c}}$ & $2006^{b}$ & $2012^{c}$ & $2006^{b}$ & $2012^{c}$ \\
\hline \multicolumn{11}{|l|}{$\begin{array}{l}\text { Metabolic conditions associated to CVD risk, } \\
\text { prevalence (\%) }\end{array}$} \\
\hline Overweight and obesity defined by $B M{ }^{a}$ & 69.7 & 71.3 & 71.5 & 72.8 & 70.2 & 71.2 & 69.3 & 70.2 & 66.6 & 71.0 \\
\hline Abdominal obesitya & 75.7 & 74.0 & 79.7 & 76.6 & 74.6 & 76.4 & 78.1 & 74.7 & 71.7 & 71.6 \\
\hline Hypertension ${ }^{a}$ & 31.6 & 31.5 & 34.2 & 36.5 & 30.1 & 29.8 & 33.5 & 32.3 & 30.0 & 28.0 \\
\hline Hypertriglyceridemia ${ }^{a}$ & $31.5[9]$ & - & 29.2 & - & 42.0 & - & 28.2 & - & 22.4 & - \\
\hline Hypercholesterolemia ${ }^{a}$ & 43.6[9] & - & 46.3 & - & 52.1 & - & 42.1 & - & 29.8 & - \\
\hline Hypoalphalipoproteinemia ${ }^{a}$ & $60.5[9]$ & - & 58.3 & - & 49.3 & - & 65.9 & - & 72.8 & - \\
\hline $\operatorname{High} L D L-c^{a}$ & $46.0[9]$ & - & - & - & - & - & - & - & - & - \\
\hline
\end{tabular}

a Overweight and obesity defined as $\mathrm{BMl} \geq 25 \mathrm{~kg} / \mathrm{m}^{2}$ and abdominal obesity as a waist circumference $\geq 80 \mathrm{~cm}$ for women and $\geq 90 \mathrm{~cm}$ for men; hypertension defined as systolic/diastolic blood pressure $\geq 140 / \geq 90 \mathrm{~mm} \mathrm{Hg}$; hypertriglyceridemia defined as triglycerides $\geq 150 \mathrm{mg} / \mathrm{dL}$, hypercholesterolemia as total cholesterol $\geq 200 \mathrm{mg} / \mathrm{dL}$, hypoalphalipoproteinemia as high-density lipoprotein cholesterol $<50 \mathrm{mg} / \mathrm{dL}$ for women and $<40 \mathrm{mg} / \mathrm{dL}$ for men and high LDL-c concentration as low-density lipoprotein cholesterol $\geq 130 \mathrm{mg} / \mathrm{dL}$.

b National Survey of Health and Nutrition 2006 (Spanish acronym: ENSANUT 2006).

c National Survey of Health and Nutrition 2012 (Spanish acronym: ENSANUT 2012). 
Table 2. Epidemiological and economic scenario related to CVD in seven mega-countries

\begin{tabular}{|c|c|c|c|c|c|c|c|}
\hline & \multicolumn{2}{|c|}{ Low-medium HDI } & \multicolumn{3}{|c|}{ High HDI } & \multicolumn{2}{|c|}{ Very High HDI } \\
\hline & India & Nigeria & México & China & Brazil & Japan & USA \\
\hline \multirow[t]{2}{*}{ Hypertriglyceridemia, \% ${ }^{\mathrm{a}}$} & $29.5[37]$ & $23.4[38]$ & $31.5[9]$ & $13.8[40]-17.7[39]$ & 23.2 (women) & $18.0[35,36]$ & $30.0[33]$ \\
\hline & & & & & 40.7 (men)[41] & & \\
\hline Hypercholesterolemia, \% ${ }^{\mathrm{a}}$ & $13.9[37]$ & $25.9[38]$ & 43.6[9] & $6.9[40]-10.1[39]$ & $\begin{array}{l}12.5 \text { (self- } \\
\text { report)[42] }\end{array}$ & $16.2[35,36]$ & $12.4[32]$ \\
\hline \multirow{2}{*}{$\begin{array}{l}\text { Hypoalphalipoproteinemia, } \\
\%^{\mathrm{a}}\end{array}$} & $72.3[37]$ & $43.8[38]$ & $60.5[9]$ & $11.0[39]-20.4[40]$ & 20.7(women) & $12.7[35,36]$ & $18.4[32]$ \\
\hline & & & & & 14.7 (men)[41] & & \\
\hline \multirow[t]{2}{*}{ High LDL-c, \%a } & $11.8[37]$ & - & $46.0[9]$ & $8.1[40]-8.8[39]$ & 57.6(women) & $11.1[35,36]$ & $27.0[34]$ \\
\hline & & & & & 58.5(men)[41] & & \\
\hline \multicolumn{8}{|l|}{ Probability of dying of } \\
\hline \multicolumn{8}{|l|}{ CVD, \% ${ }^{\mathrm{b}}$} \\
\hline 2000 & 26.6 & 25.5 & 16.8 & 21.5 & 24.4 & 11.4 & 18.0 \\
\hline 2016 & 23.3 & 22.5 & 15.7 & 17.0 & 16.6 & 8.4 & 14.6 \\
\hline \multirow{3}{*}{\multicolumn{8}{|c|}{$\begin{array}{l}\text { Age-standardized CVD } \\
\text { deaths per } 100,000 \\
\text { inhabitants }{ }^{c}\end{array}$}} \\
\hline & & & & & & & \\
\hline & & & & & & & \\
\hline 1990 & 317.7 & 248.8 & 195.8 & 332.3 & 341.8 & 183.7 & 256.1 \\
\hline 2017 & 282.3 & 181.0 & 152.8 & 261.9 & 178.0 & 79.4 & 151.1 \\
\hline \% Change & -11.1 & -27.3 & -22.0 & -21.2 & -47.9 & -56.8 & -41.0 \\
\hline \multirow{2}{*}{\multicolumn{8}{|c|}{$\begin{array}{l}\text { CVD mortality attributable } \\
\text { to risk factors in } 2017, \% \text { c }\end{array}$}} \\
\hline & & & & & & & \\
\hline Low intake of nuts and & $13.0[8.2,18.4]$ & $7.3[4.2,10.9]$ & $13.8[8.8,19.4]$ & $8.7[5.5,12.2]$ & $10.8[6.9$ & $8.9[5.6,12.6]$ & $10.7[6.4,15.4]$ \\
\hline seeds & & & & & 15.0] & & \\
\hline Low intake of PUFAs (W-3) & $11.3[5.3,18.3]$ & $7.8[3.5,12.6]$ & $8.1[3.6,14.0]$ & $6.3[2.9,10.5]$ & $5.1[2.1,9.0]$ & $0.078[0.006,0.27]$ & $6.5[2.7,11.7]$ \\
\hline High systolic blood & $53.0[47.1,58.9]$ & $58.6[52.2,64.5]$ & $49.7[42.6,57.0]$ & $54.5[47.9,61.0]$ & $53.3[47.9$, & $49.4[43.1,55.6]$ & $44.5[37.8,51.1]$ \\
\hline pressure & & & & & 58.8] & & \\
\hline High LDL cholesterol & $24.1[18.4,30.2]$ & $15.9[11.0,22.0]$ & $30.0[22.5,38.1]$ & $19.6[14.2,26.2]$ & $25.1[20.0$, & $22.1[16.2,29.2]$ & $25.1[18.8,32.1]$ \\
\hline & & & & & $30.6]$ & & \\
\hline
\end{tabular}

Expenditure on CVD

nationwide ${ }^{d}$

Total, \$US

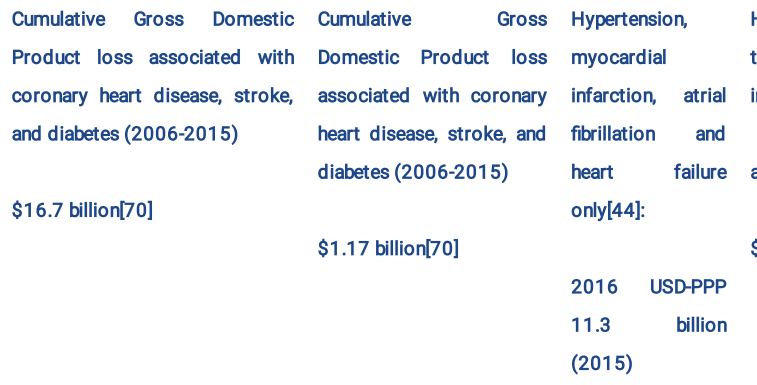

Hospitalization expenses related $\$ 11.1$ billion $\$ 109.6$ billion (2014)[68]

to acute myocardial infarction, (2015)[69]

intracranial hemorrhage,

and cerebral infarction:

$\$ 13.2$ billion (2014)[66]

on

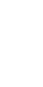

\$316.1 billion (2013) [64]

\begin{tabular}{llll} 
& \multicolumn{1}{c}{$\begin{array}{c}\text { Costs associated with } \\
\text { Economic } \\
\text { ischemic heart disease: }\end{array}$} & CVD: \\
$\begin{array}{l}\text { impact of } \\
\text { hypertension, } \$ 16.13 \text { billion }(2014)[62]\end{array}$ & $\$ 555$ billion $(2016)$ \\
heart failure, & & {$[60]$}
\end{tabular}

myocardial

infarction, and

atrial

fibrillation

$\$ 17.4$

billion[59]

(2015)

Costs of informal caregiving for patients with CVD:

$\$ 61$ billion (2015)[61]

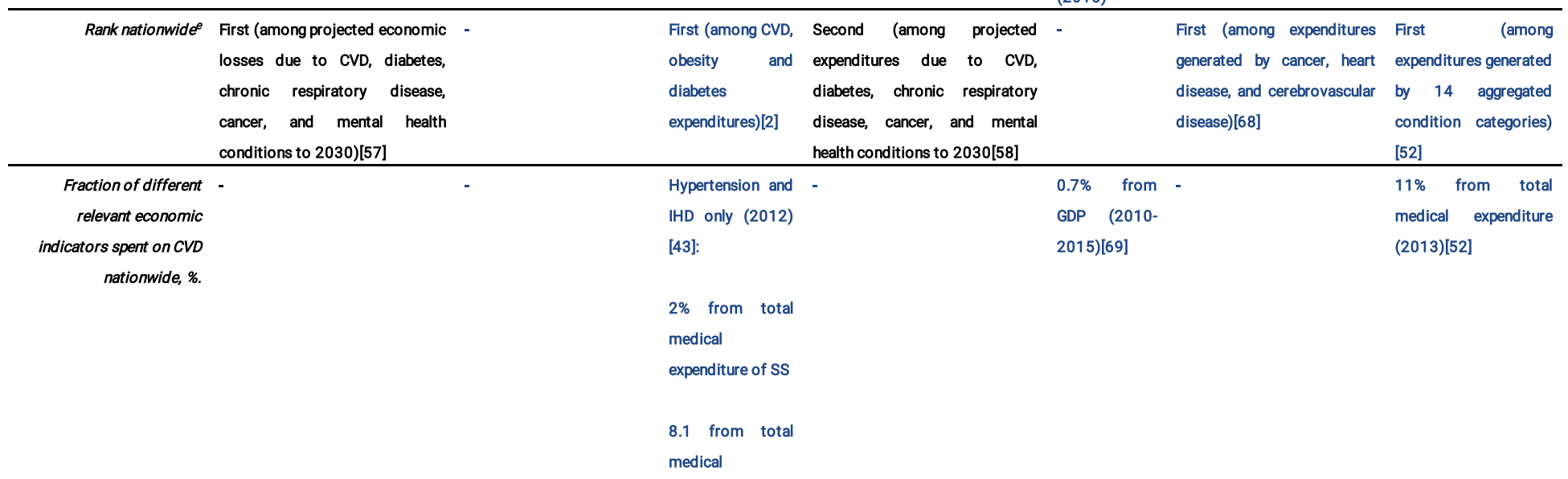

Page 25/32 
expenditure of

IMSS

$0.13 \%$ from GDP

Hypertension,

myocardial

infarction, atrial

fibrillation and

heart failure

(2015)[44]:

$4 \%$ from total

medical

expenditure

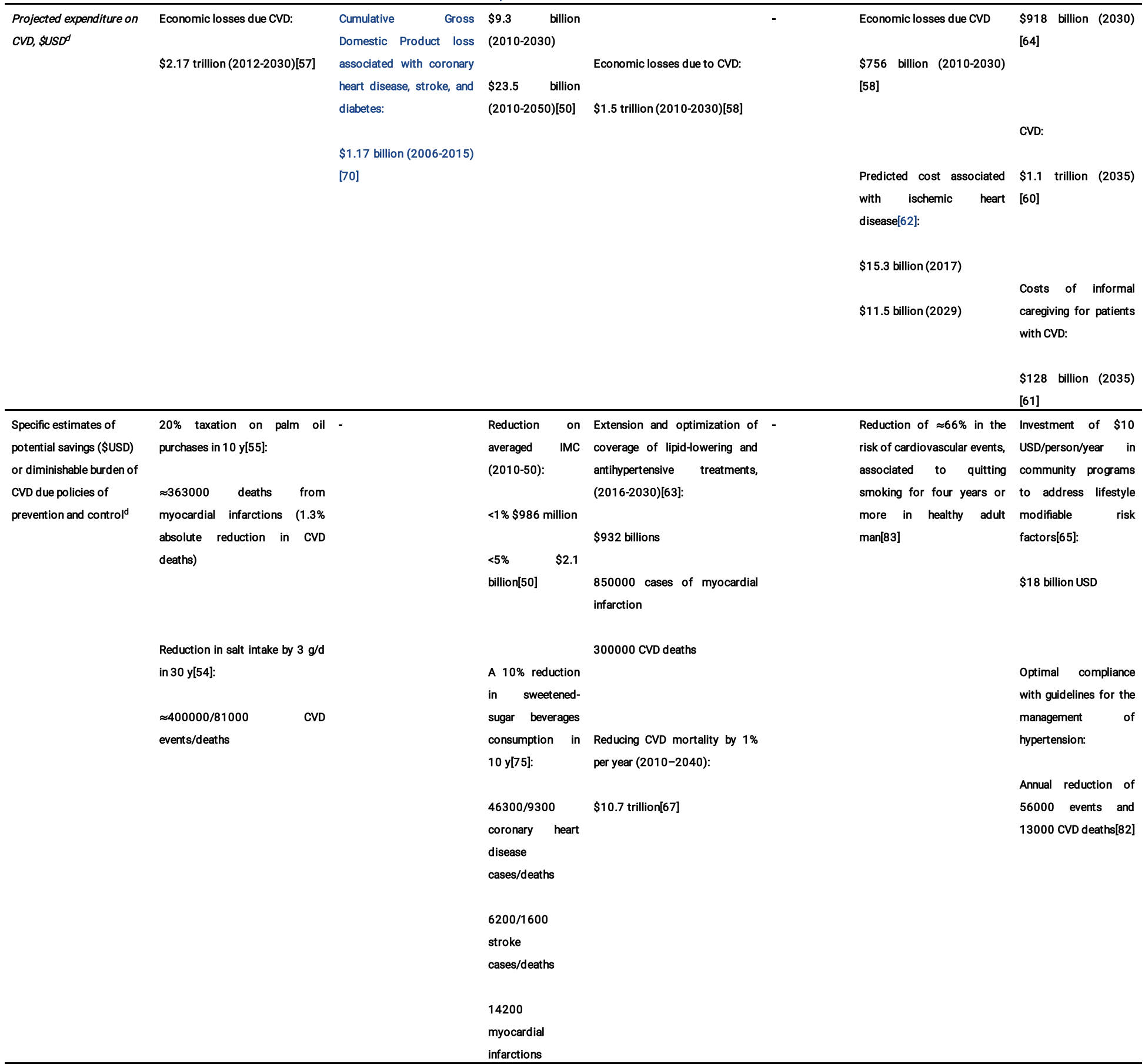




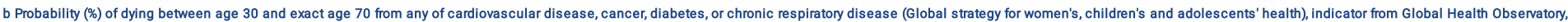

Table 3. Prevalence of Mexican adult candidates for treatments according to cardiovascular risk profiles, 2006 $\mathrm{LDL}(\mathrm{mg} / \mathrm{dL})$, ranges $(\%)$

Lifestyle changes Pharmacological treatment treatment

Cardiovascular risk profile

$<70 \quad 70-100-130-160->190 \quad$ Prevalence (\%) $99.9 \quad 129.9 \quad 159.9 \quad 189.9$

Prevalence

(\%)

$\begin{array}{llllllll}\text { Total } & 7.3 & 18.4 & 28.6 & 21.4 & 13.1 & 11.2 & 36.3\end{array}$
prevalence

(\%)

Profile 1: coronary heart disease or equivalent condition (acute myocardial infarction, stroke, non-traumatic amputation or diabetes)

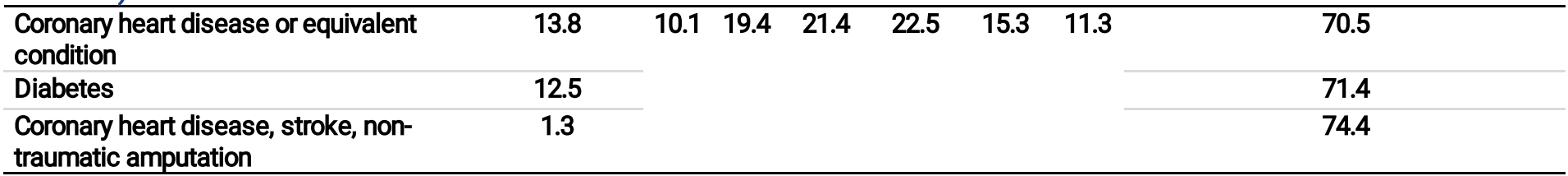

Without coronary heart disease or equivalent condition

$\begin{array}{llllllllll}\text { Two or more CVD risk factors (age } \geq 45 & 31.5 & 8.2 & 23.1 & 30.8 & 19.4 & 10.6 & 7.9 & 38.6 & 23.9\end{array}$ years for men

and $\geq 55$ years for women, family

history of coronary

disease, current smoking or

hypertension)

Profile 2: प2 CVD risk factors + 23.3

Framingham score $<10 \%$

Profile 3: प2 CVD risk factors +

Framingham score

5

5.9

$\begin{array}{llllllll}9.6 & 24.9 & 34.7 & 19.8 & 7.0 & 3.9 & 30.7 & 10.9\end{array}$

$10-20 \%$

\begin{tabular}{llllllllll}
\hline $\begin{array}{l}\text { Profile 4: } 42 \text { CVD risk factors }+ \\
\text { Framingham score }>20 \%\end{array}$ & 2.2 & 3.8 & 15.8 & 12.9 & 10.1 & 27.2 & 30.3 & 80.5 & 80.5 \\
\hline
\end{tabular}

Information adapted from:

Gómez-Pérez F, Rojas R, Villalpando S, Barquera S, Rull J, Aguilar-Salinas C. Prevention of cardiovascular disease based on lipid lowering treatment: a challenge for the Mexican health system. Salud Publica De Mexico. 2010; 52 Suppl 1S54-S62. 
Table 4. Age-standardized deaths of CVDs attributable to risk factors in Mexico, 2017

\begin{tabular}{|c|c|c|c|}
\hline $\begin{array}{l}\text { Attributable burden of dietary } \\
\text { risk factors }\end{array}$ & $\begin{array}{l}\text { Cardiovascular diseases }{ }^{\mathrm{a}} \text {, deaths per } 100,000 \\
\text { inhabitants [uncertainty interval] }(\%)^{\mathrm{b}}\end{array}$ & $\begin{array}{l}\text { Ischemic heart disease, deaths per } 100,000 \\
\text { inhabitants [uncertainty interval] }(\%)^{\mathrm{b}}\end{array}$ & $\begin{array}{c}\text { Ischemic } \\
\text { stroke, deahts } \\
\text { per } 100,000 \\
\text { inhabitants } \\
\text { [uncertainty } \\
\text { interval] (\%) }\end{array}$ \\
\hline Total & $73.9[65.3,83.5](48.4)$ & $63.0[54.6,71.5](65.7)$ & $\begin{array}{c}3.4[2.5,4.4] \\
(23.2)\end{array}$ \\
\hline Low intake of nuts and seeds & $21.1[13.4,29.7](13.8)$ & $21.1[13.4,29.7](22.0)$ & . \\
\hline Low intake of vegetables & $17.5[8.6,28.3](11.5)$ & $14.4[5.7,24.6](15.1)$ & $\begin{array}{c}1.0[0.3,1.8] \\
(6.7)\end{array}$ \\
\hline $\begin{array}{l}\text { Low intake of PUFAs ( } W-3) \\
\text { from fish and seafood }\end{array}$ & $12.4[5.5,21.2](8.1)$ & $12.4[5.5,21.2](13.0)$ & . \\
\hline Low intake of fruits & $11.3[5.3,19.1](7.4)$ & $7.0[2.2,13.5](7.3)$ & $\begin{array}{c}1.4[0.6,2.3] \\
(9.3)\end{array}$ \\
\hline High intake of trans fatty acids & $10.2[6.0,15.9](6.7)$ & $10.2[6.0,15.9](10.7)$ & $\cdot$ \\
\hline Hgh intake of sodium & $7.2[0.1,22.4](4.7)$ & $4.6[0.1,14.3](4.8)$ & $\begin{array}{c}0.6[0.01,1.9] \\
(3.9)\end{array}$ \\
\hline Low intake of fiber & $4.2[1.8,7.6](2.7)$ & $4.2[1.8,7.6](4.3)$ & . \\
\hline $\begin{array}{l}\text { Low intake of polyunsaturated } \\
\text { fatty acids }\end{array}$ & $7.8[3.3,13.1](5.1)$ & $7.8[3.3,13.1](8.2)$ & . \\
\hline High intake of processed meat & $2.4[0.1,4.9](1.6)$ & $2.4[0.1,4.9](2.5)$ & . \\
\hline Low intake of legumes & $1.8[0.5,4.1](1.2)$ & $1.8[0.5,4.1](1.9)$ & . \\
\hline $\begin{array}{l}\text { High intake of sugar- } \\
\text { sweetened beverages }\end{array}$ & $8.6[-](5.6)$ & $8.6[-](8.9)$ & . \\
\hline Low intake of whole grains & $11.5[5.7,18.9](7.5)$ & $8.8[4.2,15.1](9.1)$ & $\begin{array}{c}0.9[0.5,1.5] \\
(6.2)\end{array}$ \\
\hline \multicolumn{4}{|l|}{$\begin{array}{l}\text { Attributable burden of } \\
\text { metabolic risk factors }\end{array}$} \\
\hline Total & $118.3[109.4,126.6](77.4)$ & $80.6[72.9,88](84.1)$ & $\begin{array}{c}10.1[8.2,12.2] \\
(68.6)\end{array}$ \\
\hline High systolic blood pressure & $75.9[65.0,87.0](49.7)$ & $46.6[36.4,56.8](48.6)$ & $\begin{array}{c}6.2[4.5,8.0] \\
(41.9)\end{array}$ \\
\hline High LDL cholesterol & $45.8[34.5,58.2](30.0)$ & $42.7[31.6,54.4](44.6)$ & $\begin{array}{c}3.0[1.0,6.4] \\
(20.7)\end{array}$ \\
\hline High fasting plasma glucose & $46.6[30.6,68.2](30.5)$ & $35.4[20.4,55.9](37.0)$ & $\begin{array}{c}4.6[2.2,9.9] \\
(31.2)\end{array}$ \\
\hline Overweight and obesity & $36.5[23.1,50.3](23.9)$ & $22.5[13.5,32.2](23.5)$ & $\begin{array}{c}2.1[1.2,3.2] \\
(14.3)\end{array}$ \\
\hline Impaired kidney function & $17.2[14.5,20.2](11.3)$ & $13.7[11.2,16.4](14.3)$ & $\begin{array}{c}1.6[1.1,2.2] \\
(10.9)\end{array}$ \\
\hline
\end{tabular}

a It includes all CVDs considered by Global Burden of Disease Study by 2017.

b It refers to the attributable percentage from risk factors to the total of CVD deaths.

Information adapted from:

Institute for Health Metrics and Evaluation (IHME). GBD Compare Data Visualization. Seattle, WA: IHME, University of Washington, 2017. Available from http://vizhub.healthdata.org/gbd-compare. Accessed November 20, 2018. 
Page 29/32 
Table 5. Estimated expenditures for CVD in Mexico expressed in USD-PPP and pesos ${ }^{\mathrm{a}}$, 2006-2016

\begin{tabular}{|c|c|c|c|c|c|}
\hline \multirow[t]{2}{*}{ Author } & \multirow[t]{2}{*}{ Year } & \multirow[t]{2}{*}{ CVD/Item } & \multirow[t]{2}{*}{ Institutions } & \multicolumn{2}{|c|}{ Total expenditure nationwide } \\
\hline & & & & USD-PPP & Pesos \\
\hline \multirow{4}{*}{$\begin{array}{l}\text { Ávila- } \\
\text { Burgos et } \\
\text { al. }\end{array}$} & \multirow[t]{4}{*}{2006} & \multirow{4}{*}{$\begin{array}{l}\text { Ischemic heart disease, cerebrovascular diseases, hypertension, peripheral vascular diseases, } \\
\text { rheumatic diseases and rheumatic heart diseases, congestive heart failure, pulmonary heart } \\
\text { disease and other heart disease }\end{array}$} & Ministry of Health & $\begin{array}{c}343152856\left(48.4 \%^{b}\right) \\
\left(2.4 \%^{c}\right)\end{array}$ & 3043422684 \\
\hline & & & IMSS & $\begin{array}{c}1766349589\left(61.3^{b}\right) \\
\left(11.0 \%{ }^{c}\right)\end{array}$ & 15665754501 \\
\hline & & & ISSSTE & $\begin{array}{c}812492790\left(66.0 \%^{\mathrm{b}}\right) \\
\left(23.2^{\mathrm{c}}\right)\end{array}$ & 7205998550 \\
\hline & & & Private sector & $\begin{array}{c}723092634 \\
\left(40.5 \%^{b}\right) \\
\end{array}$ & 6413108571 \\
\hline \multirow{6}{*}{$\begin{array}{l}\text { Figueroa- } \\
\text { Lara et al. }\end{array}$} & \multirow[t]{6}{*}{2012} & \multirow[t]{2}{*}{ Hypertension } & Ministry of Health & 425901122 & 3777317057 \\
\hline & & & IMSS & 1312998401 & 11644982822 \\
\hline & & \multirow[t]{2}{*}{ Ischemic heart disease } & Ministry of Health & 107039658 & 949334732 \\
\hline & & & IMSS & 719802391 & 6383927403 \\
\hline & & \multirow[t]{2}{*}{ Both } & Ministry of Health & $532940781\left(2 \%^{c}\right)$ & 4726651789 \\
\hline & & & IMSS & $2032800792\left(8.1 \%^{\mathrm{c}}\right)$ & 18028910225 \\
\hline \multirow{5}{*}{$\begin{array}{c}\text { Stevens B } \\
\text { et al. }\end{array}$} & \multirow[t]{5}{*}{2015} & Hypertension & \multirow{5}{*}{$\begin{array}{l}\text { Complete health system } \\
\text { including loss of productivity } \\
\text { and welfare }\end{array}$} & 2645591792 & 23463753600 \\
\hline & & Heart failure & & 3148115549 & 27920636800 \\
\hline & & Myocardial infarction & & 4550683595 & 40360012800 \\
\hline & & Atrial fibrillation & & 973931131 & 8637795200 \\
\hline & & Total & & $11233946555\left(4 \%{ }^{\mathrm{d}}\right)$ & 99633872000 \\
\hline \multirow{5}{*}{$\begin{array}{l}\text { Arredondo } \\
\text { et al. }\end{array}$} & \multirow[t]{5}{*}{2015} & \multirow[t]{5}{*}{ Hypertension (adults over 60 years old) } & Ministry of Health & 585138637.9 & 5189594579 \\
\hline & & & IMSS & 985625322.1 & 8741510981 \\
\hline & & & ISSSTE & 394118027 & 3495432782 \\
\hline & & & Users & 2051383788 & 18193722816 \\
\hline & & & Total & 4022328467 & 35674031175 \\
\hline \multirow{5}{*}{$\begin{array}{l}\text { Arredondo } \\
\text { et al. }\end{array}$} & \multirow[t]{5}{*}{2016} & & Ministry of Health & 1604264783 & 14228224358 \\
\hline & & Hypertension & IMSS & 2674376729 & 23719047208 \\
\hline & & & ISSSTE & 1069487777 & 9485287094 \\
\hline & & & Users & 5566411341 & 49368502187 \\
\hline & & & Total & 10914540614 & 96801060709 \\
\hline \multirow{6}{*}{$\begin{array}{c}\text { IMSS } \\
\text { datasets }\end{array}$} & \multirow[t]{6}{*}{2016} & Total expenditure on statins by IMSS in 2016 & \multirow{6}{*}{$\begin{array}{l}\text { Estimates from IMSS } \\
\text { datasets }\end{array}$} & & \\
\hline & & Atorvastatin & & 6594810 & 58489369 \\
\hline & & Pravastatin & & 16076150 & 142579376 \\
\hline & & Average unit price in 2016 & & & \\
\hline & & Atorvastatin & & 1.1 & 9.9 \\
\hline & & Pravastatin & & 1.08 & 9.6 \\
\hline
\end{tabular}

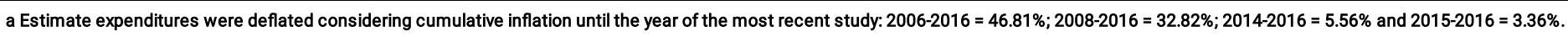

Then, estimates were adjusted by purchasing power parities (PPP) for 2016 (1 USDPPP = 8.87 pesos).

b Fraction from total chronic disease expenditures spent on CVD, \%.

c Fraction from total budget per institution spent on CVD, \%.

d Fraction from total healthcare expenditure in Mexico.

Information adapted from:

Avila-Burgos L, et al. Accounts in diabetes mellitus, cardiovascular diseases and obesity, Mexico 2006. Mexico City/Cuernavaca, Mexico: National Institute of Public Health, 2009.

Figueroa-Lara A, et al. Medical Expenditure for Chronic Diseases in Mexico: The Case of Selected Diagnoses Treated by the Largest Care Providers. Plos One. $2016 ; 11$ (1): e0145177.

Stevens B, Pezzullo L, Verdian L, et al. The economic burden of hypertension, heart failure, myocardial infarction, and atrial fibrillation in Mexico. Arch Cardiol Mex. April 2018.

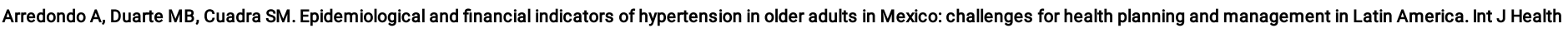
Plann Manage. 2017;32(2):e121e136.

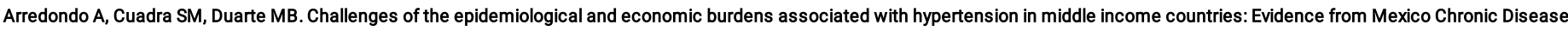
epidemiology. BMC Public Health. 2015;15(1):1-7.

Instituto Mexicano del Seguro Social (IMSS). Portal de compras del IMSS. http://compras.imss.gob.mx/. Accessed July 9, 2018. 


\section{Figures}

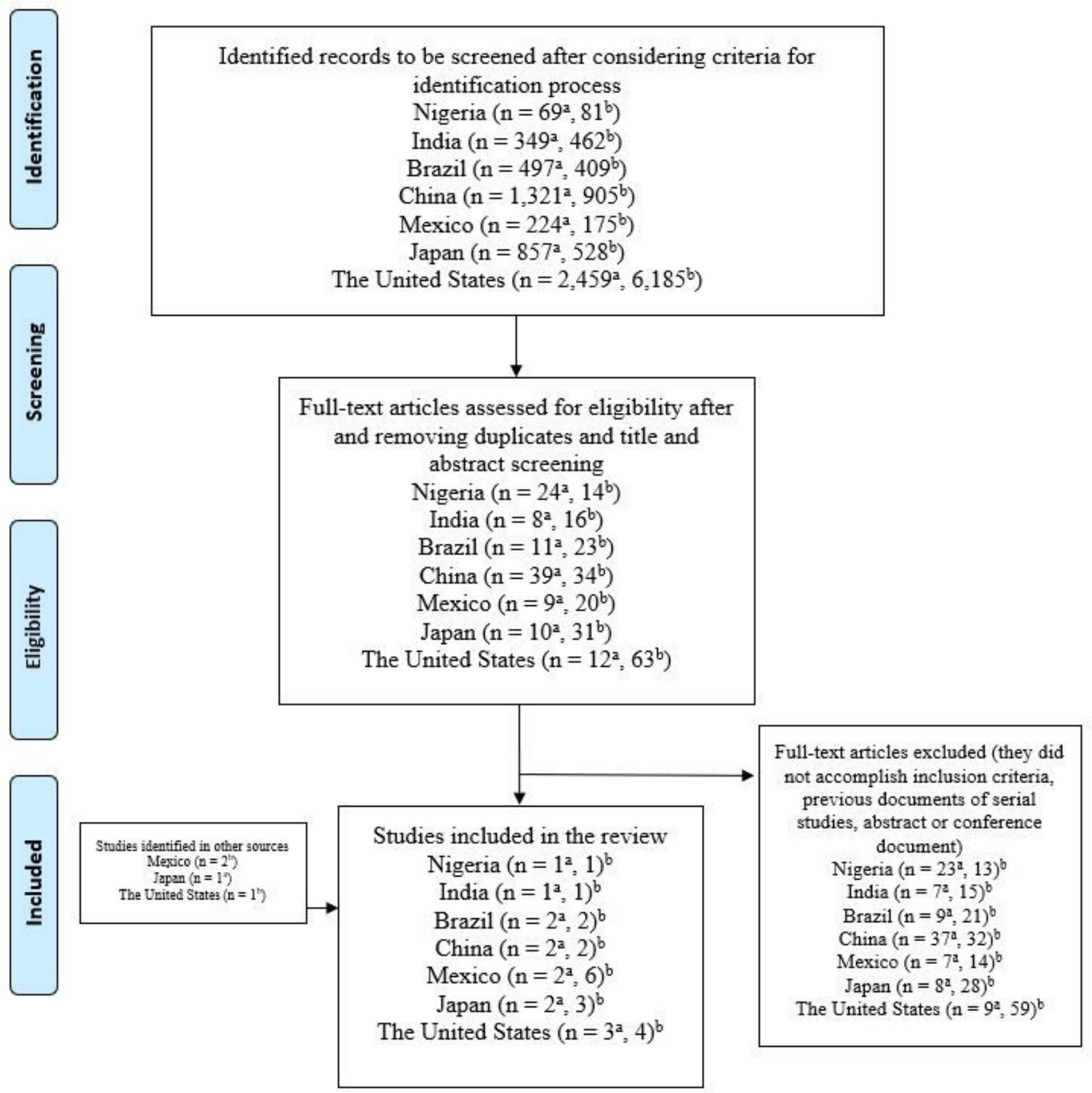

Figure 1

PRISMA flow diagram, literature review for seven mega-countries. a Search for dyslipidemia b Search for economic burden of cardiovascular diseases 


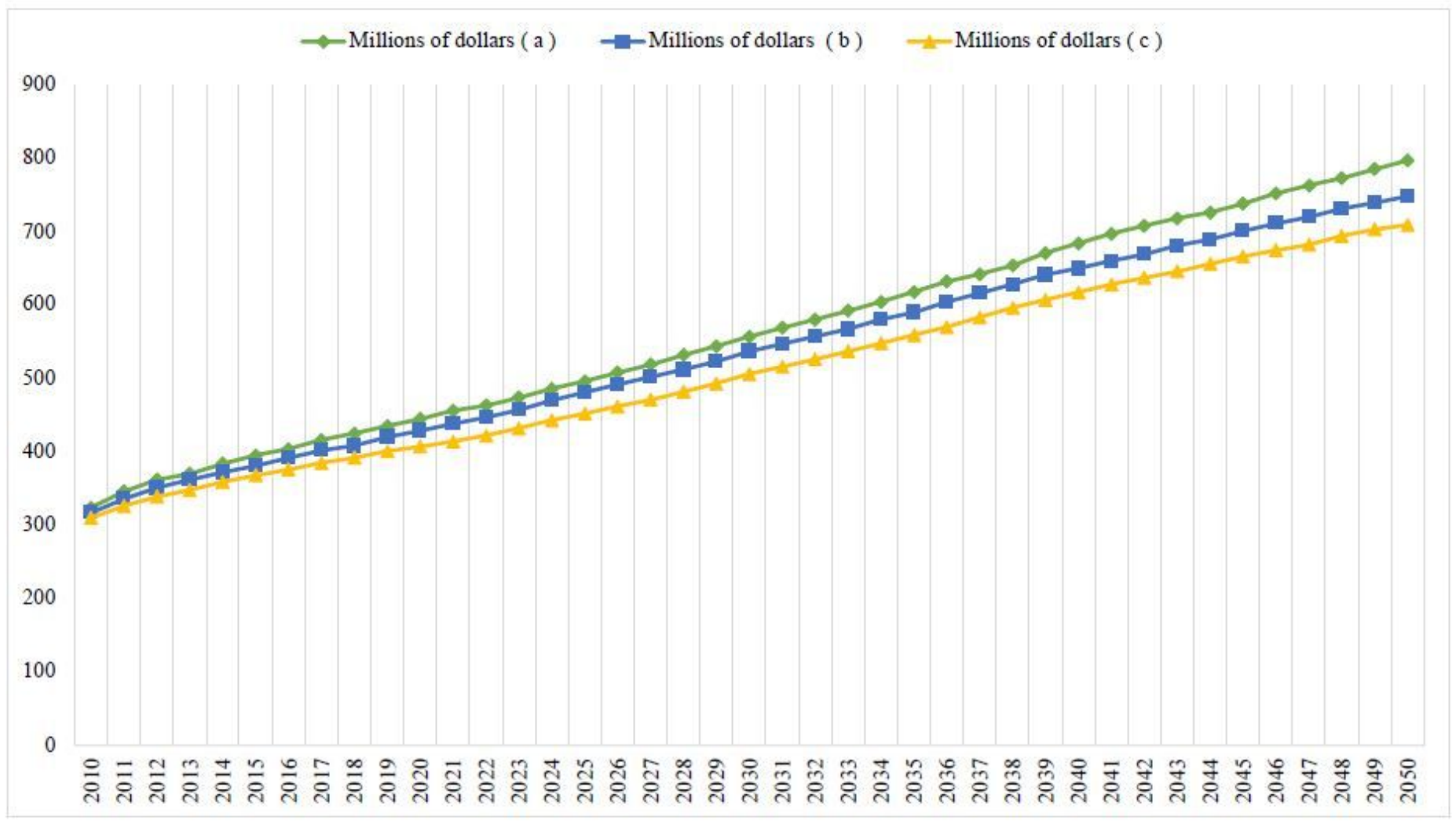

Figure 2

Projected costs of ischemic heart disease, acute myocardial infarction, and stroke. Mexico 2010-2050. a No BMI reduction. $b$ Reduction of $1.0 \%$ in the average BMI (mean BMI of $28.5 \mathrm{~kg} / \mathrm{m} 2$ to $28.2 \mathrm{~kg} / \mathrm{m} 2$ ). c Reduction of $5.0 \%$ in the average BMI (mean BMI of $28.5 \mathrm{~kg} / \mathrm{m} 2$ to $27.1 \mathrm{~kg} / \mathrm{m} 2$ ). Exchange rate USD, 2010: approximately $\$ 12.60$ pesos. Information adapted from: Rtveladze K, Marsh T, Barquera S, Sanchez Romero L, Levy D, Brown M, et al. Obesity prevalence in Mexico: impact on health and economic burden. Public Health. 2014; 17(1): $233-239$.

\section{Supplementary Files}

This is a list of supplementary files associated with this preprint. Click to download.

- Additionalfile1PRISMAchecklist.docx

- Additionalfile2Supplementarymaterial2.docx 